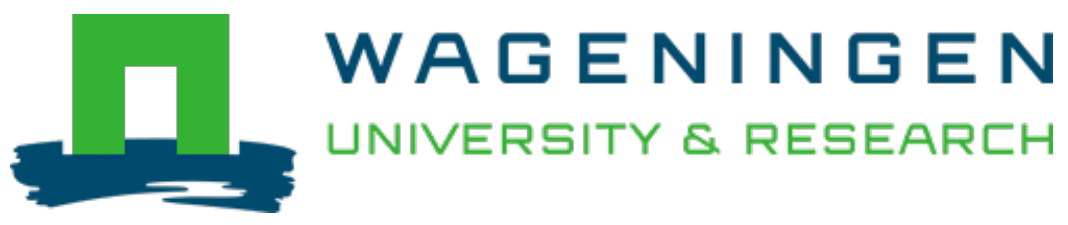

\title{
Coagulation and precipitation of cyanobacterial blooms
}

Ecological Engineering

Lürling, Miquel; Kang, Li; Mucci, Maíra; Oosterhout, Frank; Noyma, Natalia Pessoa et al https://doi.org/10.1016/j.ecoleng.2020.106032

This article is made publicly available in the institutional repository of Wageningen University and Research, under the terms of article $25 \mathrm{fa}$ of the Dutch Copyright Act, also known as the Amendment Taverne. This has been done with explicit consent by the author.

Article $25 \mathrm{fa}$ states that the author of a short scientific work funded either wholly or partially by Dutch public funds is entitled to make that work publicly available for no consideration following a reasonable period of time after the work was first published, provided that clear reference is made to the source of the first publication of the work.

This publication is distributed under The Association of Universities in the Netherlands (VSNU) 'Article $25 \mathrm{fa}$ implementation' project. In this project research outputs of researchers employed by Dutch Universities that comply with the legal requirements of Article $25 \mathrm{fa}$ of the Dutch Copyright Act are distributed online and free of cost or other barriers in institutional repositories. Research outputs are distributed six months after their first online publication in the original published version and with proper attribution to the source of the original publication.

You are permitted to download and use the publication for personal purposes. All rights remain with the author(s) and / or copyright owner(s) of this work. Any use of the publication or parts of it other than authorised under article $25 \mathrm{fa}$ of the Dutch Copyright act is prohibited. Wageningen University \& Research and the author(s) of this publication shall not be held responsible or liable for any damages resulting from your (re)use of this publication.

For questions regarding the public availability of this article please contact openscience.library@wur.nl 


\title{
Coagulation and precipitation of cyanobacterial blooms
}

\author{
Miquel Lürling ${ }^{\mathrm{a}, \mathrm{b}, *}$, Li Kang ${ }^{\mathrm{a}}$, Maíra Mucci ${ }^{\mathrm{a}}$, Frank van Oosterhout ${ }^{\mathrm{a}}$, Natalia Pessoa Noyma ${ }^{\mathrm{c}}$, \\ Marcela Miranda ${ }^{c, d}$, Vera L.M. Huszare, Guido Waajen ${ }^{\mathrm{f}}$, Marcelo Manzi Marinho ${ }^{\mathrm{c}}$ \\ ${ }^{a}$ Aquatic Ecology \& Water Quality Management Group, Department of Environmental Sciences, Wageningen University, P.O. Box 47, 6700 AA Wageningen, The \\ Netherlands \\ ${ }^{\mathrm{b}}$ Department of Aquatic Ecology, Netherlands Institute of Ecology (NIOO-KNAW), P.O. Box 50, 6700 AB Wageningen, The Netherlands \\ ${ }^{\mathrm{c}}$ Laboratory of Ecology and Physiology of Phytoplankton, Department of Plant Biology, University of Rio de Janeiro State, Rua São Francisco Xavier 524-PHLC Sala \\ 511a, 20550-900 Rio de Janeiro, Brazil \\ ${ }^{\mathrm{d}}$ Earth System Science Center (CCST), National Institute for Space Research (INPE), Av. dos Astronautas, 1.758 - Jardim da Granja, 12227-010 São José dos Campos, SP, \\ Brazil \\ ${ }^{\mathrm{e}}$ Museu Nacional, Federal University of Rio de Janeiro, 20940-040 Rio de Janeiro, Brazil \\ ${ }^{\mathrm{f}}$ Water Authority Brabantse Delta, Team Knowledge, P.O. Box 5520, 4801 DZ Breda, The Netherlands
}

\section{A R T I C L E I N F O}

\section{Keywords:}

Geo-engineering

Lake restoration

Managing cyanobacterial nuisance

P control

Phoslock

Alum

\begin{abstract}
A B S T R A C T
Eutrophication is the prime water quality issue in inland waters. Eutrophication and its key symptom, harmful cyanobacterial blooms, is expected to further increase in the future, which highlights the importance of managing the issue. The reduction of external nutrient load is crucial but might not bring fast relief to eutrophic waters due to ongoing diffuse pollution and legacy nutrients in the sediment. In this context, in-lake measures are needed to speed-up recovery. In this review, we discuss different in-lake measures based on coagulation and precipitation of cyanobacteria and/or phosphate for different lake categories (e.g., shallow or deep, mainly external or internal nutrient load, occurrence of perennial or summer blooms). In deep lakes with an external nutrient load higher than the internal load, a "Floc and Sink" method could be used in which a coagulant (e.g. aluminium salts, Al-salts; chitosan) combined with a ballast (e.g. soil, clay) removes a cyanobacterial bloom out of the water column. In case the deep lake suffers from high internal load, a phosphate (P)-fixative (e.g. lanthanum modified bentonite or Al-salts) can be used to "Lock" the legacy P, possibly combined with a coagulant a "Floc and Lock" technique. The latter approach will target both the particulate $\mathrm{P}$ in a bloom and the internal P load. A shallow lake that suffers from summer blooms and in which the internal load is higher than the external load, a "Lock" strategy of winter application of a P-fixative is proposed to prevent bloom development. In shallow lakes with perennial blooms, an agent to damage the cells (such as $\mathrm{H}_{2} \mathrm{O}_{2}$ ) is required together with a coagulant and a ballast to avoid recolonization of the water column due to resuspension - a "Kill, Floc and Sink/ Lock" method. The selection of the most promising in-lake measures and materials should be based on a proper system diagnosis and tests prior to a full-scale intervention. These methods can be effective, but evidently reduction of external nutrient loads, both from point- and non-pointed sources, is an absolute necessity to restore aquatic ecosystems in a holistic sense.
\end{abstract}

\section{Introduction}

The over-enrichment with nutrients (i.e. eutrophication) of lakes, ponds and reservoirs is one of the most important water quality issues (Downing, 2014). Eutrophication may lead to drastic ecosystem changes, such as loss of submerged plants, a decrease in water transparency, an overgrowth of algae, increase of planktivorous- and benthivorous fish, an accumulation of organic matter and a large, recyclable sediment phosphorus (P) pool (Moss, 2010). The most notorious symptom of eutrophication is a massive proliferation of cyanobacteria (Paerl et al., 2011). Blooms of cyanobacteria are viewed problematic as they may produce nasty odours, cause fish kills due to hypoxia/anoxia, and may impair ecosystem services, such as drinking water production, irrigation, recreation, aquaculture and fisheries (Paerl and Paul, 2012). Eutrophication is expected to further increase in the upcoming decades because of human population growth, intensified

\footnotetext{
* Corresponding author at: Aquatic Ecology \& Water Quality Management Group, Department of Environmental Sciences, Wageningen University, P.O. Box 47, 6700 AA Wageningen, The Netherlands.

E-mail address: miquel.lurling@wur.nl (M. Lürling).
} 
agricultural activities and climate change (Cordell et al., 2009; Jeppesen et al., 2009; Moss et al., 2011; Sinha et al., 2017; Beaulieu et al., 2019). As a result, increased incidence, intensity and duration of cyanobacterial blooms in lakes, ponds and reservoirs are expected (Paerl and Huisman, 2008; O'Neil et al., 2012; Paerl and Paul, 2012; Huisman et al., 2018). Hence, mitigating eutrophication and controlling cyanobacterial blooms is of high importance to authorities and water managers.

The first step to counteract eutrophication is to reduce the external nutrient inputs (e.g., Hamilton et al., 2016; Paerl et al., 2016; Huisman et al., 2018). Targeting the cause of the problem is the most logical management strategy because a massive proliferation of cyanobacteria can occur only when all nutrients are abundantly available. Here, however, the wickedness of the problem is recognized, as it is already known for many decades that eutrophication fuels nuisance cyanobacterial blooms and therewith impairs water quality (Edmondson et al., 1956; Parma, 1980). Nonetheless, eutrophication is still a widespread problem (OECD, 2017), which illustrates the overall difficulty in adequate lowering of nutrient inputs into surface water. The impact of point source nutrient pollution, such as untreated wastewater, is already known since the 1950 -ies and even in Europe, with the implementation of all sorts of policies over the past decades, improved wastewater treatment, discharge and storm water management is still needed in many countries (Ibisch et al., 2016). In low-income countries less than $10 \%$ of the municipal and industrial wastewater undergoes treatment of any kind (WWAP, 2017). Huge upfront investments will be needed in those countries to improve sewerage coverage and sewage treatment (van Loosdrecht and Brdjanovic, 2014). Tackling point sources such as wastewater effluents, however, gives no guarantee that eutrophication threats will vanish. In several cases, external point source load reduction did not yield the expected outcome and eutrophic conditions remained (Cullen and Forsberg, 1988), while in other lakes recovery was delayed by years to decades (Fastner et al., 2016), which is due to legacies and diffuse nutrient loads (OECD, 2014, 2017). For instance, urban wastewater treatment in the Netherlands is in full compliance with the Urban Waste Water Treatment Directive. Virtually all wastewater is treated and has $100 \%$ compliance for the elimination of nutrients by tertiary treatment (EU, 2013). Nonetheless, the Netherlands has one of the poorest surface water qualities of the European Union (EEA, 2018). Legacies from the past, sewage overflows and diffuse pollution from mostly agricultural activities cause this ongoing impact on water quality (OECD, 2014) and make eutrophication still a major threat to waters around the globe (Ibisch et al., 2016; OECD, 2017).

Evidently, merely controlling external point sources is often insufficient to reverse eutrophication and additional nutrient control measures are needed (Paerl et al., 2016). Catchment measures to reduce diffuse nutrient sources are essential to restore aquatic ecosystems in a holistic sense (Steinman, 2019), however, they may involve many stakeholders and thus time before fully implemented, or there may simply be no space for such measures as in urbanized areas (Huser et al., 2016a). All in all, continued leaching from nutrient saturated soils in the catchment, recycling from nutrient-loaded sediments, together with changed biological make-up of eutrophic lakes will postpone improved water quality for decades to centuries (Jarvie et al., 2013; Rissman and Carpenter, 2015; Goyette et al., 2018). Consequently, a rapid diminishing of cyanobacterial blooms is not to be expected, unless in-lake interventions are implemented.

In-lake interventions encompass a great variety of different approaches, such as biomanipulation on fish and macrophytes, reconstruction of the reservoir/lake, dredging, water column mixing, use of algaecides and so on (Lürling and Mucci, 2020). In this review, the focus is on the coagulation and precipitation of cyanobacteria and/or phosphate as promising tools to manage eutrophication and its nuisance.

\section{In-lake measures}

The cyanobacterial nuisance could be tackled immediately in many lakes using in-lake measures that would bring direct relief. Such interventions are particularly needed in situations where users of cyanobacteria infested waters simply have no time 'to sit this one out' or wait for many years until eventually external load control has been implemented and water quality improves. In-lake measures can be curative or symptom-oriented, such as flushing, mixing, targeting biomass, and/or preventative or source-oriented, such as increasing critical nutrient load level, lowering the nutrient load and improving water transparency via food web manipulations (reviewed in Stroom and Kardinaal, 2016; Lürling and Mucci, 2020).

The symptom-oriented interventions are intended to target the cyanobacteria directly. Direct targeting of cyanobacteria is commonly done cost-effectively with algaecides (Jančula and Maršálek, 2011). Copper-based algaecides are most frequently used to control nuisance algae (e.g., Iwinski et al., 2016), while novel algaecides are being developed to minimize unwanted side effects (Matthijs et al., 2016). Algaecides induce cyanobacterial cell lysis. Cell lysis may liberate nutrients (Coloma et al., 2017) and cause the release of intracellular toxins (Jones and Orr, 1994; Jančula and Maršálek, 2011).

Alternatives to cell-lysing algaecides are interventions based on coagulation, flocculation and removal of cyanobacterial biomass. Here, the use of mineral/metal-based, natural, organic and synthetic coagulants (Lee et al., 2014) can be considered to aid aggregation, floatation and dewatering (e.g., http://waterned.com/), or when combined with a ballast to effectively sink the aggregates to the sediment - a "Floc and Sink" approach (Fig. 1A) (Pan et al., 2011a; Lürling and Oosterhout, 2013; Waajen et al., 2016a). Such interventions can immediately swipe a water column clear of cyanobacteria without releasing toxins and nutrients. This type of intervention seems best suited for deep, stratifying lakes with ongoing external nutrient load, as the cyanobacteria can be removed effectively from the epilimnion and brought to the sediment in a cold and darker hypolimnion (Fig. 1A). A combination of a coagulant (floc) and phosphate (P) sorbent (to lock P) can not only clear a water column of particles, but also reduce $\mathrm{P}$ from the water column and reduce the sediment $P$ release (Waajen et al., 2016a). This "Floc and Lock" approach can be useful in lakes with a legacy P load (van Oosterhout et al., 2020a), especially in deep, stratifying lakes (Fig. 1B). The group of compounds that have strong $\mathrm{P}$ binding capacities are viewed as promising geo-engineering materials (Douglas et al., 2016; Lürling et al., 2016a).

In shallow lakes, however, a "Floc and Sink" or "Floc and Lock" approach might not be as efficient as in deep waters, because flocs are fluffy, can be resuspended and cyanobacteria easily be liberated from the flocs that subsequently may recolonise the water column rapidly (Fig. 1C). External load control is an absolute necessity in those waters, where in-lake measures such as biomanipulation could be implemented to speed-up recovery. Otherwise, both in a perennial blooms scenario or recurring summer blooms, repeated use of algaecides such as hydrogen peroxide might be an option (Matthijs et al., 2016). In shallow lakes with low external load, but a relatively large internal load, preferably the cyanobacteria are killed first before settled to the sediment (Fig. 1D). Alternatively, only a P-fixative is used before the growing season taking away the fuel for the blooms.

\section{3. 'Floc and Sink' of cyanobacteria}

In marine systems, algae can be precipitated using a clay as a single measure (Sengco et al., 2001; Deng et al., 2015). In contrast in freshwater, solely adding clay or other 'ballast compounds' will hardly lead to the removal of cyanobacteria as net electrostatic repulsive force between negatively charged clay particles and cyanobacteria prevent collision (Noyma et al., 2017), unless the cyanobacteria themselves are sticky (Verspagen et al., 2006). Consequently, efficient removal of 


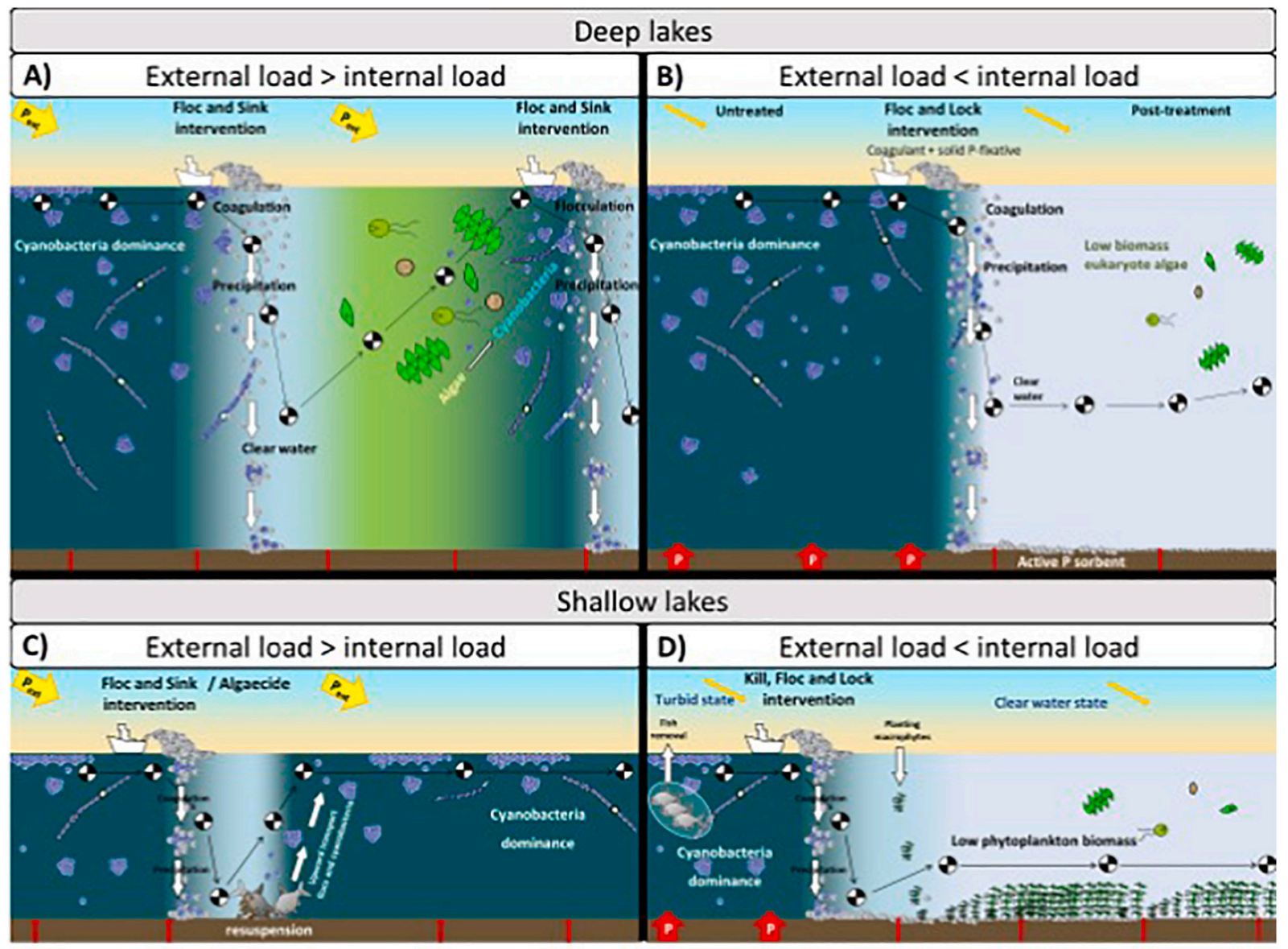

Fig. 1. "Floc and Sink" intervention can effectively precipitate cyanobacteria in a deep, stratifying lake until external load has refuelled the epilimnion for regrowth (panel A). In a deep lake with mostly internal load fuelling blooms, a "Floc and Lock" treatment can remove a water column of cyanobacteria and phosphate, whilst a P-fixative minimizes the sediment P release (panel B). In shallow lakes, resuspension will rapidly bring flocs with living cells back in the water column (panel C). External load reduction is needed, use of algaecides can be considered. In a shallow lake with mainly internal load, cyanobacteria also could be killed before "Floc and Lock" and additional measures (fish removal, planting macrophytes) may be needed to facilitate a rapid shift to a clear water state (panel D). In deep lakes and shallow lakes with high internal load a winter intervention using a P-fixative only ("Lock") could also suffice. Secchi disks illustrate changes in water transparency. Xaxis indicates time.

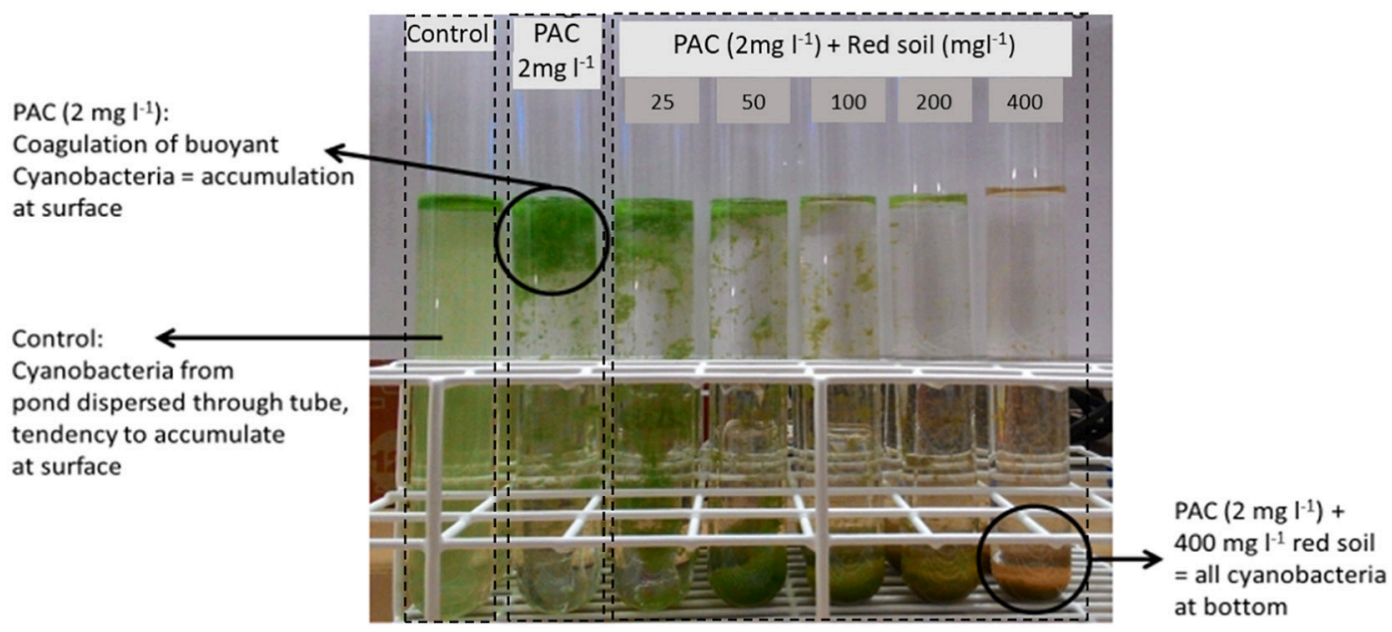

Fig. 2. Example of a short-term "Floc and Sink" assay (1.5 h) with cyanobacteria infested water (Microcystis aeruginosa, $\sim 350 \mu \mathrm{g} 1^{-1}$ chlorophyll-a) without treatment (control), treated with solely the coagulant (PAC, $2 \mathrm{mg} \mathrm{Al}^{-1}$ ) and treated mixtures of PAC with different doses (25 to $400 \mathrm{mg} 1^{-1}$ ) of red soil as ballast.

cyanobacteria in freshwater systems can only be achieved by the combination of a dose of coagulant and a ballast (Pan et al., 2006; Zou et al., 2006; Noyma et al., 2016). In this so-called "Floc and Sink" technique (Noyma et al., 2016), different coagulants and ballast compounds can be used that - before being applied at a specific site need to be tested in a laboratory-based "Floc and Sink" assay first to yield insight on their performance and dose needed (Fig. 2).

Coagulants can be metal-based, such as aluminium sulphate (alum), 
poly-aluminium chloride (PAC) and iron(III)chloride (Pan et al., 2011a; Lürling and Oosterhout, 2013; Waajen et al., 2016a; de Lucena-Silva et al., 2019), organic polymers like chitosan (Pan et al., 2006, 2011b; Noyma et al., 2016, 2017) and cationic starch (Shi et al., 2016), synthetic organic coagulants like cationic polyacrylamides (Jančula and Maršálek, 2011) and cationic polyamine (Dai et al., 2015), or extracts derived from Moringa oleifera seeds (Oladoja and Pan, 2015; Camacho et al., 2017; de Oliveira Ruiz Moreti et al., 2019).

Ballast compounds may be local soils, clay, bauxite, gravel (e.g., Pan et al., 2006, 2011a; Li and Pan, 2015; Noyma et al., 2016, 2017; Miranda et al., 2017; de Lucena-Silva et al., 2019), or modified clays and products with P adsorption capacity (e,g., Lürling and Oosterhout, 2013; Noyma et al., 2016, 2017; Waajen et al., 2016a). The latter is a special case of "Floc and Sink" (Noyma et al., 2016) as it is also aimed at removing phosphate from a water column and reducing sediment $\mathrm{P}$ release: a "Floc and Lock" approach (Lürling and Oosterhout, 2013), which will be discussed in detail in the next section.

The choice of coagulant and ballast compounds will be based on safety, costs, availability and efficacy. Testing selected combinations with water from the specific site is required as a priori determination of coagulation efficiency and best dose is impossible (Figs. 2 and 3). Removal efficacy between $88 \%$ and $99 \%$ removal could be reached (Noyma et al., 2017). At higher cyanobacterial biomass, more ballast is needed to achieve good removal (Noyma et al., 2017). This efficient removal of cyanobacteria by combining a low dose of coagulant and ballast can be achieved without changing the cell surface charge or zeta potential (Noyma et al., 2017). The coagulants bridge between particles, create flocs that entrap cyanobacteria and subsequently sweep through the water column entrapping more cyanobacteria cells (Huang and Chen, 1996; Yu and Somasundaran, 1996; Li et al., 2013; Yang et al., 2016; Noyma et al., 2017).

Coagulation efficacy depends on several factors such as speciesspecific characteristics (Lama et al., 2016), temperature (Xiao et al., 2008), mixing intensity (Du et al., 2020) and water chemistry as not all coagulants are equally suited in all water types (Lürling et al., 2017). The $\mathrm{pH}$ of the water seems to affect coagulation efficacy of most coagulants. Chitosan was most effective at $\mathrm{pH}$ below 8 (Lürling et al., 2017), but was not an effective coagulant at elevated pH 9-10 (Morales et al., 1985; Vandamme et al., 2013). Alum was most effective at pH 5-9, while lime with magnesium could effectively flocculate algae at
pH 10-11 (Friedman et al., 1977). Comparing the efficacy of four coagulants in removing $M$. aeruginosa in water from Lake Dianchi (China) yielded that alum and iron sulfate were effective in a $\mathrm{pH}$ range from 6 to 8, while PAC and polymeric iron sulfate (PFS) were effective in $\mathrm{pH}$ range of 5 to 8 (Ma et al., 2015). At pH 9, alum still removed $70 \%$ and the other three coagulants removed $78-82 \%$ of the $M$. aeruginosa (Ma et al., 2015).

Because hydrogen ions are released during hydrolysis of aluminiumbased coagulants, they may cause a decline in the $\mathrm{pH}$ of lakes and buffers may be needed (Cooke et al., 2005). PAC causes less pH reduction than alum and also has the advantage that a lower dose is needed, and better coagulation is achieved at lower temperatures (Gebbie, 2001; de Julio et al., 2010).

Application of aluminium formulations (PAC, alum) in waters with pH 6-8 is generally considered safe (Cooke et al., 2005; Jančula and Maršálek, 2011) and generation of toxic aluminium species - positively charged ions at $\mathrm{pH}<5.5$ and negatively charged aluminate at $\mathrm{pH}>8.5$ - is not to be expected (see Fig. 8.1 in Cooke et al., 2005). Nonetheless, potential issues in this $\mathrm{pH}$ range cannot be excluded, such as suffocation of fish by polymerized aluminium (Poléo, 1995), weight loss of fish and short-term effects on macrofauna (Smeltzer et al., 1999). Hence, environmental friendliness of metal-based coagulants has been questioned, with the promotion of organic, degradable coagulants such as chitosan as a "biodegradable, non-toxic material" (e.g., Renault et al., 2009). Chitosan, however, has antibacterial, antimicrobial, and antifungal activities (e.g., Kong et al., 2010; Younes et al., 2014), leading to bacterial cell membrane damage (Liu et al., 2004). Indeed, chitosan caused cell membrane damage in several cyanobacteria (Mucci et al., 2017), causing cell leakage (Pei et al., 2014) and leakage of cyanotoxins in field samples dominated by Cylindrospermopsis raciborskii (Miranda et al., 2017). Inasmuch as coagulated cyanobacteria may otherwise stay alive, chitosan induced cell lysis could decrease the chance of recolonization of the water column and, thus, is not per se a drawback (Mucci et al., 2017).

Chitosan is the preferred coagulant in the "modified local soil induced ecological restoration" (MLS-IER) technology in which local soil (near the bank of a lake) can be modified by adding a small amount of biodegradable coagulant (Pan et al., 2011b). The MLS-IER method combines both removal of phytoplankton biomass and conversion of their nutrients into submerged macrophytes (Pan et al., 2011b). The

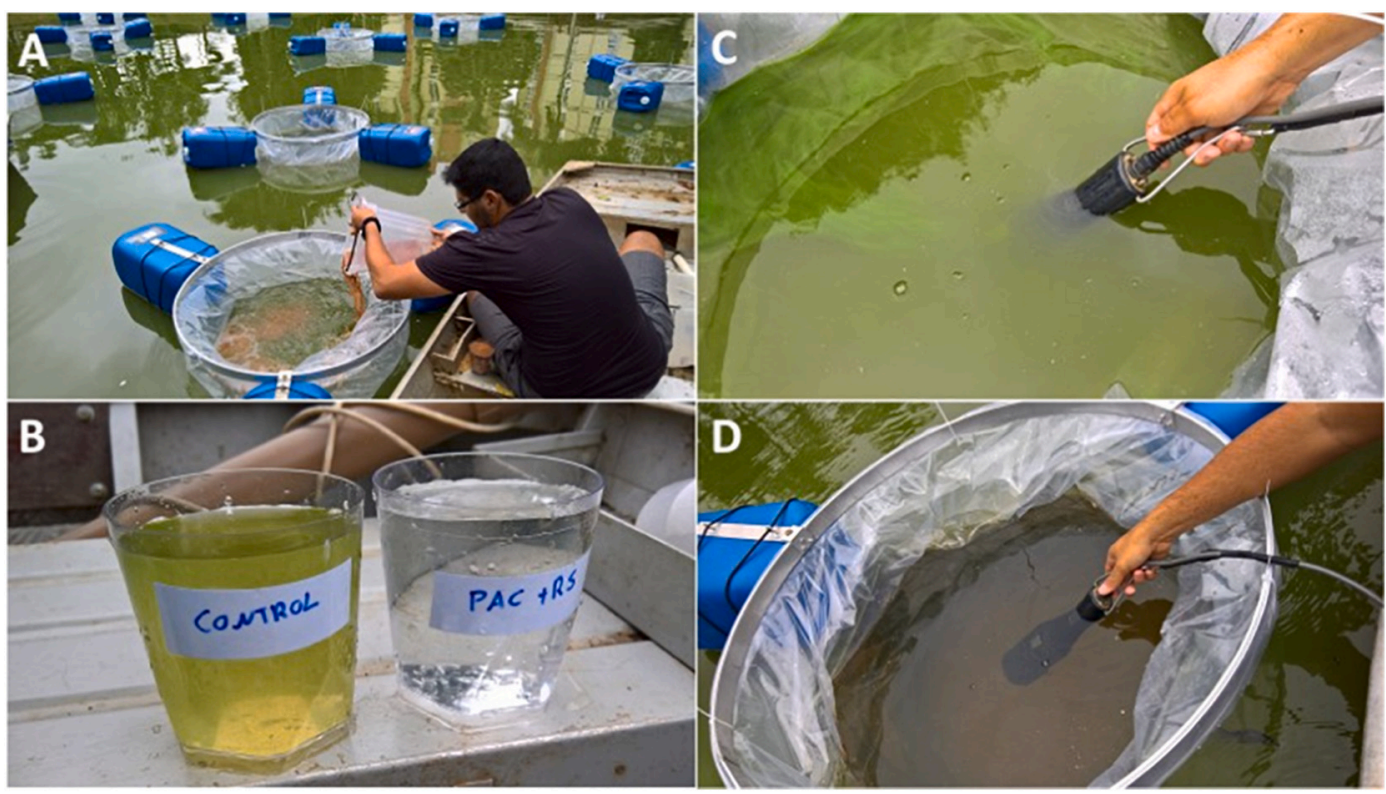

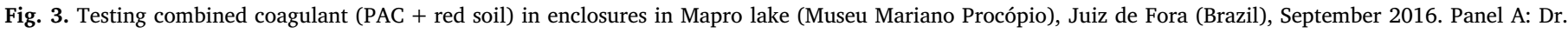
Felipe Pacheco dosing red soil. Panel B: the effect after one day. Panel C: a control enclosure. Panel D: a treated enclosure. 
combination can be effective in settling cyanobacteria, lowering algal resuspension, reducing nutrient fluxes, and decreasing microcystins release from settled flocs (Li and Pan, 2015; Pan et al., 2012). Moreover, the coagulation-capping treatment may promote cell lysis and stimulate submerged macrophyte growth (Zhang et al., 2018). The latter is of crucial importance in shallow water bodies where a shift from a phytoplankton dominated state to a macrophyte dominated state is desired (Scheffer et al., 1993). This has occurred in a field trial in Liaoyangyuan bay (North Taihu Lake, China), where treatment of the $0.1 \mathrm{~km}^{2}$ bay with $40-50 \mathrm{~g}$ MLS $\mathrm{m}^{-2}$ removed the cyanobacteria bloom and promoted growth of the macrophyte Potamogeton crispus in a few months to densities of $1 \mathrm{~kg} \mathrm{~m}^{-2}$ (Pan et al., 2011b). Treatment of a 400 $\mathrm{m}^{2}$ pond in Taixi bay (China) with $16 \mathrm{~kg}$ of chitosan-MLS (i.e. $40 \mathrm{~g}$ MLS $\mathrm{m}^{-2}$ ) strongly reduced chlorophyll-a concentrations and nutrients and improved transparency from $5 \mathrm{~cm}$ to $1.5 \mathrm{~m}$ (Pan et al., 2019). Likewise, treatment of an $800 \mathrm{~m}^{2}$ pond in Cetian Reservoir (China) with $32 \mathrm{~kg}$ of chitosan-PAC MLS improved water quality and yielded a macrophyte coverage of $65 \%$ after four months (Pan et al., 2019). A switch to a clear water state with submerged macrophytes can, however, only be achieved when the nutrient load is below the upper critical level for the transition from clear to turbid water (see Fig. 7). In addition, the fetch is of great importance as settled flocs could be resuspended. For instance, Huang et al. (2015) reported that cyanobacteria derived material, which was settled with chitosan modified clay, was resuspended at a shear stress of $0.109 \mathrm{~N} \mathrm{~m}^{-2}$ that corresponds to a low wind velocity of around $3-4 \mathrm{~m} \mathrm{~s}^{-1}$. Those authors prevented resuspension by adding sand, however at a dose of $14 \mathrm{~kg} \mathrm{~m}^{-2}$, which equals 140 ton ha $\mathrm{ha}^{-1}$ (Huang et al., 2015), and implies such capping will become economically unfeasible. Consequently, wind effects constrain the application of a "Floc and Sink" approach in wind-exposed, large, shallow lakes (Fig. 1C).

\section{4. 'Floc and Lock' of cyanobacteria and phosphate}

The term "Floc and Lock" describes interventions in which cyanobacteria are aggregated and transported to the sediment in flocs ("Floc"), whilst water column phosphate and sediment phosphate release are reduced by chemical binding ("Lock"). This can be done by combining a coagulant and a P fixative as ballast or by using an aluminium salt as coagulant and $\mathrm{P}$ binder.

\subsection{Geo-engineering using aluminium salts}

When aluminium sulphate (alum) or poly-aluminium chloride (PAC) are added to the water column, $\mathrm{Al}(\mathrm{OH})_{3}$-flocs are formed to which phosphate is adsorbed and particulate P (e.g., inside cyanobacteria) is trapped in flocs that subsequently may sink to the sediment. Once on the sediment, the remaining $\mathrm{P}$ adsorption capacity of the aluminium flocs will intercept $\mathrm{P}$ released from the sediment (Cooke et al., 2005). The different aluminium formulations have a density of around $1.3 \mathrm{kgl}^{-1}$, which ensures that, at a sufficient dose, flocs will become heavy enough to settle and therewith clear the water column from suspended particles. Such water clearing effect was already demonstrated in the first alum treatment. Ten tons of granular alum were added to the Swedish Lake Långsjön in early summer 1968: transparency improved immediately from a few dozens of $\mathrm{cm}$ to a visible bottom ( $3 \mathrm{~m}$ ), total P was reduced by $95 \%$ and for the first time in decades no cyanobacterial summer bloom formed (page 68 in Butusov and Jernelöv, 2013). Since the first application in Lake Långsjön hundreds of lakes have been treated with alum of which most were successful in blocking the release of mobile P from sediments (Cooke et al., 2005). Similar results can be obtained with PAC. For instance, addition of PAC to the hypertrophic Lake Sønderby (Denmark) caused a 93\% reduction in the internal $\mathrm{P}$ loading in the two post-treatment years relative to pretreatment internal P loading (Reitzel et al., 2005).

A meta-analysis on 114 alum treated lakes revealed improved water quality with a mean treatment longevity of 21 years in deeper, stratified lakes and a mean of 5.7 years in shallow, polymictic lakes (Huser et al., 2016b). Sediment disturbance by bottom-feeding fish (carp) was identified as a major factor reducing the longevity of the treatment in shallow lakes (Huser et al., 2016b), because already moderate densities of carp can increase the sediment mixed layer from $5 \mathrm{~cm}$ without carp to $16 \mathrm{~cm}$ with carp, which may liberate a large pool of mobile sediment $\mathrm{P}$ to the water column (Huser et al., 2016c). In addition, $\mathrm{Al}(\mathrm{OH})_{3}$-flocs are fluffy and are easily resuspended and redistributed (Egemose et al., 2010). When the $\mathrm{Al}$ flocs are resuspended into the water with a $\mathrm{pH}$ above 8.5, flocs may dissolute, form aluminate-ions and release $\mathrm{P}$ (Van Hullebusch et al., 2003; Reitzel et al., 2013a).

In lake restoration with aluminium compounds, mostly alum $\left(\mathrm{Al}_{2}\left(\mathrm{SO}_{4}\right)_{3} \cdot n \mathrm{H}_{2} \mathrm{O}\right)$ has been used (Cooke et al., 2005), which contains sulphate. Adding substantial amounts of sulphate to surface waters, however, may stimulate internal eutrophication, because bacteria may transform sulphate to sulphide that subsequently attacks iron in iron-P minerals in the top sediment forming pyrite and mobilising P (e.g., Smolders et al., 2006). Alum can be dosed in a one-time application, a "shock and awe approach", aimed to inactivate all mobile P in the top sediment (Cooke et al., 2005). Such approach has a higher risk of undesired side effects that may be lowered by repeated lower dose applications, which may also reduce the loss of $\mathrm{P}$ adsorption capacity as aluminium flocs start to age once formed (e.g., de Vicente et al., 2008).

Despite the fact that aluminium-based treatments tackle water column $\mathrm{P}$, mobile $\mathrm{P}$ in the sediment and have an instantaneous positive effect on water transparency, potential side effects stimulated search of water authorities and lake managers for alternative $\mathrm{P}$ fixatives that should be effective and safe (Spears et al., 2013a; Douglas et al., 2016). These P-fixatives are referred to as geo-engineering materials, which are used to manipulate biogeochemical processes to achieve a desired chemical and/or ecological response (Spears et al., 2014). A wide variety of geo-engineering materials exists that can be divided into four categories: 1) naturally occurring minerals or soils, 2) natural or synthetically produced materials, 3) modified clay minerals or soils, and 4) mining, mineral processing and industrial by-products (Douglas et al., 2004, 2016; Spears et al., 2013a). A detailed overview of the most important representatives of P-adsorptive materials in each category is provided by Douglas et al. (2016). In a "Floc and Lock" context, the lanthanum modified bentonite (LMB) Phoslock ${ }^{\circledR}$ has been applied (Lürling and Oosterhout, 2013; Waajen et al., 2016 a,b).

\subsection{Geo-engineering using $L M B$}

LMB was developed by CSIRO in 1990-ies (Douglas, 2002) and some years later made commercially available as Phoslock ${ }^{\circledR}$. LMB is a bentonite clay which is enriched up to a $5 \%$ mass fraction with lanthanum as active ingredient via an exchange of cations in the clay interlayers (Douglas, 2002; Douglas et al., 2004). Lanthanum is not redox sensitive and has strong affinity for phosphate with which it precipitates as the $\mathrm{LaPO}_{4}$ mineral - rhabdophane $\left(\mathrm{K}_{\mathrm{sp}}=10^{-24.7}\right.$ to $\left.10^{-25.7} \mathrm{~mol}^{2} \mathrm{l}^{-2}\right)$ (Johannesson and Lyons, 1994; Liu and Byrne, 1997). Rhabdophane is stable at least in the pH range 5-9 (Copetti et al., 2016); LMB showed excellent phosphate removal when tested in the $\mathrm{pH}$ range 6-9 (Mucci et al., 2018).

Meanwhile, LMB has been applied in around 200 water bodies worldwide (Copetti et al., 2016). These waters range from golf course ponds, in which $\mathrm{P}$ and cyanobacteria blooms could be reduced drastically (Bishop and Richardson, 2018), to larger lakes like the 130 ha Lake Goldap, Poland (Lürling et al., 2020). Application doses ranged from as low as $0.1 \mathrm{t} \mathrm{LMB} \mathrm{ha}{ }^{-1}$ to as high as $6.7 \mathrm{t} \mathrm{LMB} \mathrm{ha}^{-1}$ (Spears et al., 2013b). A detailed overview of the scientific knowledge on LMB to manage eutrophication in surface waters has been published by Copetti et al. (2016). That review wraps together data of extensive testing at laboratory, mesocosm, and whole lake scales. A meta-analysis on $18 \mathrm{LMB}$ treated lakes revealed greatly improved water quality in two 
years post-application compared to two years pre-application (Spears et al., 2016). High-resolution dialysis (HR-Peeper) and diffusive gradients in thin films (DGT) confirmed that mobile $\mathrm{P}$ was strongly reduced by LMB in sediment (Wang et al., 2017), while sediment core incubations showed a strong reduction of the sediment $\mathrm{P}$ release after LMB dosing (Waajen et al., 2016b). Sediment analysis of 10 LMB treated lakes by ${ }^{31} \mathrm{P}$ MAS NMR and La $\mathrm{L}_{\text {III }}$ EXAFS spectroscopy confirmed rhabdophane $\left(\mathrm{LaPO}_{4} \cdot n \mathrm{H}_{2} \mathrm{O}\right)$ and to lesser extent monazite $\left(\mathrm{LaPO}_{4}\right)$ was formed (Dithmer et al., 2016), which are highly resistant rare earthphosphate minerals (Douglas et al., 2004). Since these minerals will not release any P under normal natural conditions (Douglas et al., 2016), it provides solid proof of permanent inactivation of $P$ in those sediments.

LMB can remove phosphate as efficient in brackish water (1.5-15 ppth) or seawater (32 ppth) as in freshwater (Reitzel et al., 2013b; Bishop et al., 2014; Mucci et al., 2020) and reduce sediment P-release (de Magalhães et al., 2019). However, analysis of LMB in water of 4 ppth and 32 ppth revealed pushing out of La from the clay interlayers, forming La-oxyanion precipitates, which may hamper its applicability in saline environments when dosed from the water surface (Mucci et al., 2020). La leaching has also been observed in low alkalinity waters, which seems to be mostly facilitated by complexation of La with humic acids (Reitzel et al., 2017). All in all, exposure to LMB treated water is unlikely to pose a health risk to animals and/or humans (D'Haese et al., 2019; Behets et al., 2020) and to date, no indications for long-term negative effects on LMB-treated ecosystems have been found (Copetti et al., 2016; Van Oosterhout et al., 2020a).

\subsection{Geo-engineering using coagulants and $L M B$}

The first application of LMB combined with PAC as coagulant was done in the Dutch bathing site Lake Rauwbraken (Lürling and Oosterhout, 2013; van Oosterhout et al., 2020a, 2020b; Fig. 4). Lake
Rauwbraken (2.6 ha, max. depth $15 \mathrm{~m}$ ) suffered from intensifying cyanobacterial blooms culminating in a four-month swimming ban in 2007. In April 2008, the developing bloom was terminated effectively by using a coagulant (PAC, $1.1 \mathrm{mg} \mathrm{Al} 1^{-1}$ ) and 2 tons of LMB as ballast that was added from a barge and aggregated and settled the cyanobacteria (Fig. 4A). Besides an immediate settling out of the cyanobacteria, the intervention reduced the chlorophyll- $a$ concentration from an average of $16.5 \mu \mathrm{g} \mathrm{l}^{-1}$ before to $5.5 \mu \mathrm{g}^{-1}$ after the intervention and total-P from $134 \mu \mathrm{g} 1^{-1}$ to $14 \mu \mathrm{g}^{-1}$ for more than 10 years (van Oosterhout et al., 2020b; Fig. 4B).

Before the 2008 intervention, internal loading (5.0 $\mathrm{mg} \mathrm{P} \mathrm{m}^{-2} \mathrm{~d}^{-1}$ ) made up $80 \%$ of the total $\mathrm{P}$ load $\left(6.2 \mathrm{mg} \mathrm{P} \mathrm{m}^{-2} \mathrm{~d}^{-1}\right)$. Internal P load was reduced to $1.8 \mathrm{mg} \mathrm{P} \mathrm{m}^{-2} \mathrm{~d}^{-1}$ in 2011 , while the external P-load had increased from $1.2 \mathrm{mg} \mathrm{P} \mathrm{m}^{-2} \mathrm{~d}^{-1}$ before 2008 to $1.4 \mathrm{mg} \mathrm{P} \mathrm{m}^{-2}$ $\mathrm{d}^{-1}$ in 2011 (van Oosterhout et al., 2020b). Because the main external $\mathrm{P}$ load sources (water birds $\sim 0.7 \mathrm{mg} \mathrm{P} \mathrm{m}^{-2} \mathrm{~d}^{-1}$, leaf litter $\sim 0.35 \mathrm{mg} \mathrm{P}$ $\mathrm{m}^{-2} \mathrm{~d}^{-1}$, groundwater $\sim 0.2 \mathrm{P} \mathrm{m}^{-2} \mathrm{~d}^{-1}$ ) are difficult to control, repeated interventions will be required to maintain an acceptable bathing water quality. The system-analysis, more specific the cost-benefit analysis of it, underpinned that the treatment costs of $€ 50.000$,- were far less than the $€ 150.000$,- costs from a loss of revenue (visitors pay an entrance fee) of the four months swimming ban in 2007 prior to the intervention (pers. comm. Jan Hamming; alderman of Tilburg municipality). The entrance fee is $€ 5.50$ per visit nowadays (https:// derauwbraken.nl/strandbad/, assessed April 8th 2020). Given that the "Floc and Lock" treatment of Lake Rauwbraken created good water quality since its application in 2008 (van Oosterhout et al., 2020a, 2020b; Fig. 4B), the annual costs for improved water quality boil down to around $€ 4000$,- per year, which is less than $5 \%$ of the fee per visitor to Lake Rauwbraken. Hence, this intervention was cost-effective. Repeated LMB interventions would be the most logic; once every decade seems reasonable for this lake, which implies annual costs lower than

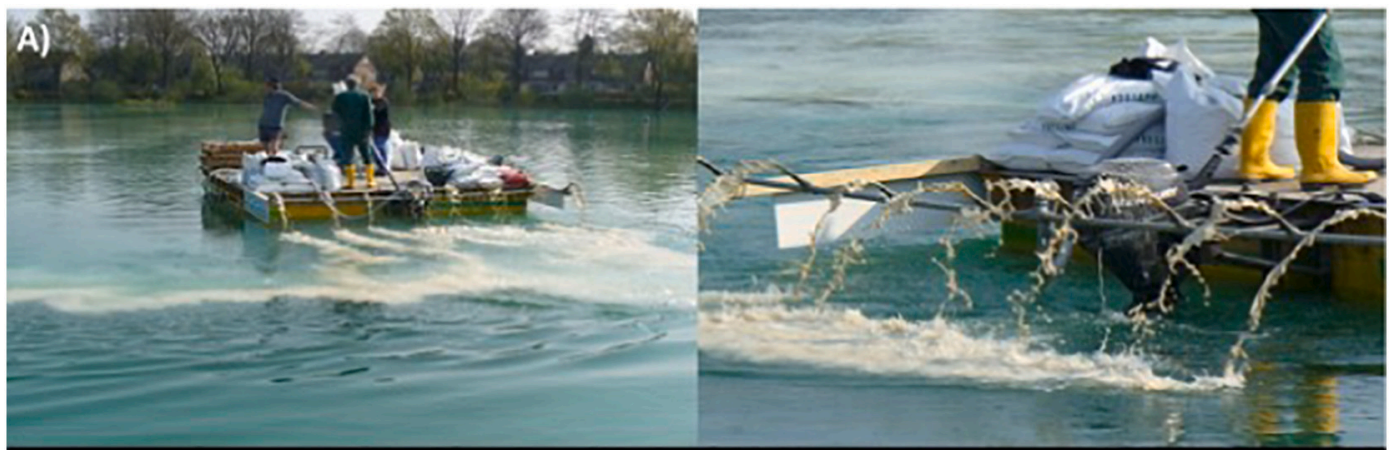

B)

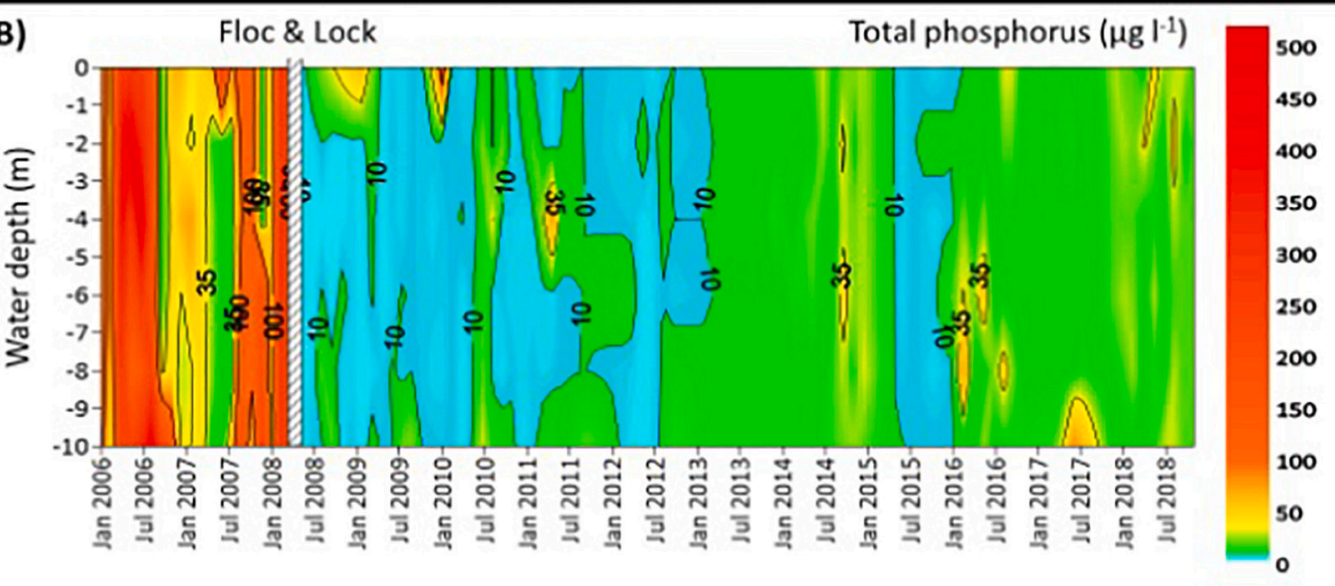

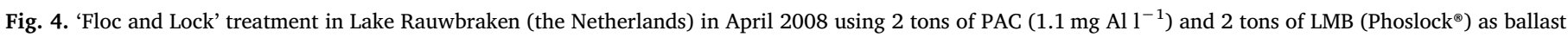

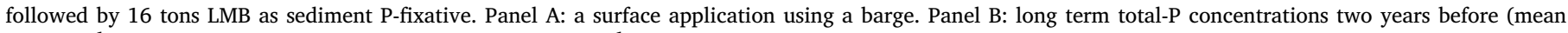
$134 \mu \mathrm{g} \mathrm{l}^{-1}$ ) and ten years after the intervention (mean $14 \mu \mathrm{g} \mathrm{l}^{-1}$ ). 
the maintenance of the beach.

Another "Floc and Lock" example is Lake De Kuil, a 6.7 ha, maximum depth $9 \mathrm{~m}$ sand excavation used as swimming lake. The lake was treated with 4.38 tons $\mathrm{FeCl}_{3}$ as a coagulant, 13.65 tons LMB as ballast (determined in jar tests prior to the intervention), while 28.25 tons of LMB were injected in the hypolimnion to target sediment $\mathrm{P}$ release (Waajen et al., 2016a). The LMB dose was based on water column P and potential releasable $P$ in the top $5 \mathrm{~cm}$ of the sediment yielding $465 \mathrm{~kg} P$ that needed to be immobilized (Waajen et al., 2016a). This "Floc and Lock" intervention (cost $€ 140.000$ ) effectively precipitated a developing cyanobacterial bloom and shifted the lake from a eutrophic to a mesotrophic state, which lasted for eight years (Waajen et al., 2016a) and came down to less than $€ 1.50$ per visitor. The lake has been without swimming bans and was retreated in May 2017 to counteract ongoing diffuse P-load. 10.05 tons of ballast LMB were added to the water surface followed by 6 tons PAC as a coagulant and thereafter 22.05 tons of LMB were injected into the hypolimnion. The authorities decided to execute a reapplication of $\sim € 100.000$, because it was most cost-effective. Bartoszek and Koszelnik (2015) mentioned treatment of Jelonek and Winiary lakes (Poland) with an injection of PIX 111 as a coagulant $\left(\mathrm{FeCl}_{3}\right)$ and $\mathrm{LMB}$ directly into the sediment. However, the effectiveness of this application is not yet known.

\section{Problem diagnosis and lake type characterization}

Not a single water body is an exact copy of another and, thus, "each lake has to be studied before restoration measures can be applied" (Van Liere and Gulati, 1992). This means that a proper system analysis deciphering the water and nutrient fluxes and therewith the nutrient loading of the water body, as well as its biological characteristics should always be conducted before implementation of measures, as it will indicate what kind of measures will be most promising (Cooke et al., 2005; Lürling et al., 2016a; Stroom and Kardinaal, 2016). Reality is, however, quite different; only in a few cases has the choice for specific measures been explained (Stroom and Kardinaal, 2016) and copy-paste of measures seems more a rule than an exception. For instance, the majority of lake restoration (bio-manipulation) projects in The Netherlands failed, because of neglecting in-lake nutrient loading (Gulati and Van Donk, 2002), which implies no system analysis had been conducted.

The system analysis will identify if external nutrient load, internal load or both are driving cyanobacterial nuisance, or if the nuisance is merely caused by physical accumulation on leeside shore of otherwise low water column dispersed biomass. In situations where the external nutrient load is the main issue, reduction of external nutrient inputs is the most logic first management strategy (e.g., Hamilton et al., 2016; Paerl et al., 2016; Huisman et al., 2018), Without additional in-lake measures, however, recovery is predicted to take decades to centuries (Søndergaard et al., 1999; Carpenter, 2005; Cooke et al., 2005). To control outbreaks of cyanobacterial blooms in deep, stratifying lakes a "Floc and Sink" approach can be considered (Fig. 5A). Cyanobacteria can be brought to the sediment, leaving a clear and low nutrient epilimnion until the external load has reloaded it allowing re-establishment of the bloom (Fig. 1). In contrast, in large, shallow, wind-exposed lakes, coagulation and sinking will be of limited to no-use as flocs are easily resuspended and cyanobacteria liberated (Fig. 5B). In smaller, shallow lakes, a "Floc and Sink" approach can be considered, but only when cyanobacteria are killed to reduce the possibility of recolonization of the water column (Fig. 5B). This "Kill, Floc and Sink" combination has been tested in a laboratory setting using hydrogen peroxide as algaecide, polymeric ferric sulphate as a coagulant, lake sediment as ballast (Wang et al., 2012), and with calcium peroxide as an algaecide, chitosan as a coagulant and red soil as ballast (Noyma et al., 2016). To our knowledge, the only in situ test has been performed in an enclosure experiment in Juiz de Fora (Brazil) using hydrogen peroxide as algaecide, PAC as coagulant and red soil as ballast (unpublished). Hydrogen peroxide will damage the cyanobacteria and nutrient release from the lysed cells may stimulate regrowth; a ballast with P-binding properties could be considered. Clearly, these symptom-oriented, in-lake measures are far from ideal, cannot be implemented in each lake type, need to be repeated regularly and, thus, should not only be effective and safe but also be cheap.

In deep, stratifying lakes with a relatively large internal load, strong reduction of the sediment $P$ release could be a strategy for (speeding up) recovery. Dosing a P-fixative before the growing season, or combined with a coagulant during growing season, or when the lake suffers from perennial blooms could be considered (Fig. 5A). In a large, shallow lake, a P-fixative that keeps binding capacity until all binding site are occupied could be considered. Even when resuspended, ongoing $P$ removal would imply strong competition with cyanobacteria. In case, cyanobacteria abundance is relatively high, $P$ from the cells needs to be liberated first (Fig. 5B). In smaller, shallow lakes, immobilizing P before the growing season, combined with bottom resuspension fish removal and macrophyte introduction could be a promising strategy. Such combination of measures has been tested in $400 \mathrm{~m}^{2}$ compartments in 2009-2011 (Waajen et al., 2016b; Fig. 6) and a "Lock and Grow" approach with planting charophytes following a Phoslock ${ }^{\circledR}$ treatment has been executed successfully in the small Lake Reithersee (Reith im Alpbachtal, Austria) (Epe et al., 2020).

The rationale for combined measures is rooted in the feedback mechanisms that stabilise alternative states in shallow lakes: the turbid, phytoplankton-dominated state and the clear water state with submerged macrophytes (Scheffer et al., 1993; Fig. 7). The transitions from clear to turbid and from turbid to clear occur at different nutrient loadings due to state self-enforcing mechanisms (Scheffer et al., 1993). Nutrient loadings need to be reduced much further to enforce a shift to clear water than at which the water became turbid (Fig. 7). However, when bottom-resuspending fish (bream, carp) are abundant in densities of hundreds of $\mathrm{kg}$ per hectare (Waajen et al., 2014), the water will remain in a turbid state by resuspending sediments and preventing submerged macrophyte establishment (e.g., Cline et al., 1994; Roozen et al., 2007). Consequently, fish density should be reduced to preferably less than $50 \mathrm{~kg}$ per hectare (Gulati and Van Donk, 2002) and macrophyte introduction could be considered. Measures that do not reduce the nutrient load to below the upper transition (from clear to turbid water), will at best only temporarily alleviate cyanobacterial nuisance (Fig. 7) and, thus, repeated interventions are needed to control cyanobacterial blooms in such high nutrient load systems (Fig. 5). The needed curative interventions should be effective, easy, safe and affordable (Table 1).

Special cases are oligo- and oligo-mesotrophic lakes where the cyanobacterial nuisance is caused by an accumulation of cyanobacteria present in low amounts in the water column. Direct targeting of the accumulation seems the most straightforward intervention (Fig. 5A). This is usually done applying algaecides (Jančula and Maršálek, 2011; Matthijs et al., 2016). The algaecide treatment could be followed by a coagulant/ballast dose to bind cyanotoxins and nutrients released from killed cells (Kill-Floc-Sink/Lock approach). For instance, combined chitosan-nano scale montmorillonite not only effectively precipitated Microcystis aeruginosa cells ( $94 \%$ removal), but also removed $90 \%$ of the extracellular microcystins within one hour (Wang et al., 2015). Likewise, LMB $(50,100$, and $150 \mathrm{ppm})$ decreased microcystin concentrations by $61.2,86.0,75.4 \%$ relative the controls, respectively (Laughinghouse IV et al., 2020).

\section{Widespread application of geo-engineering in lakes, ponds, and reservoirs}

Hundreds of aluminium based treatments have been performed in lakes varying from a few to several hundreds of hectares in size as well as in small ponds (Cooke et al., 2005; Huser et al., 2016b). LMB has been applied to over 200 lakes up to a few dozens of ha (Spears et al., 

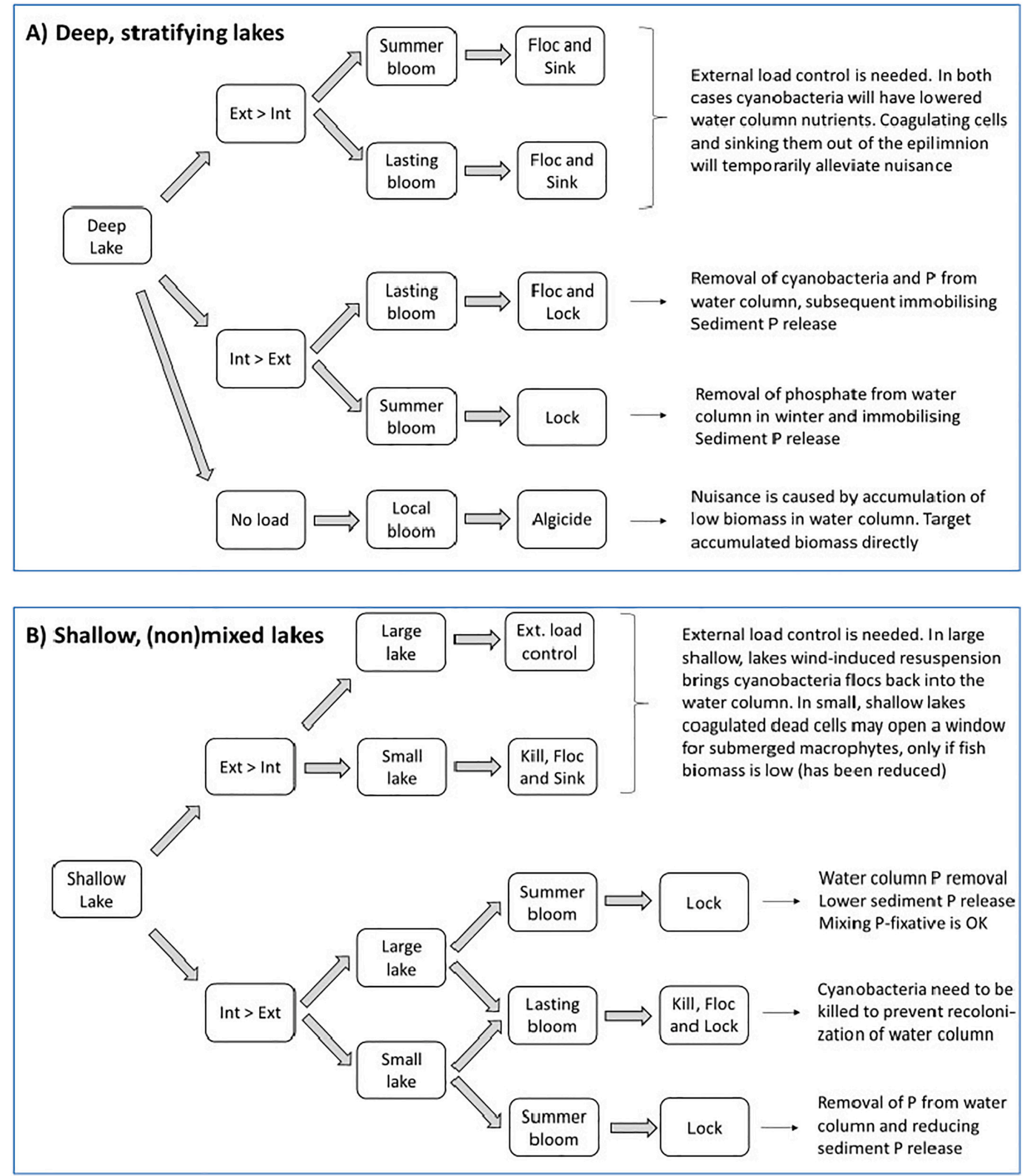

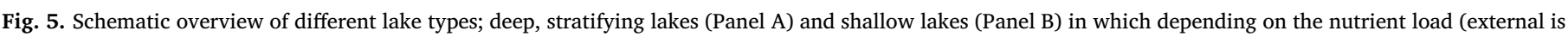

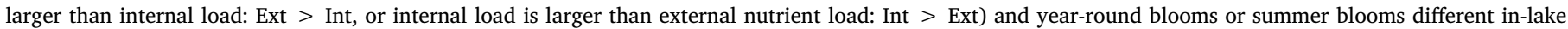

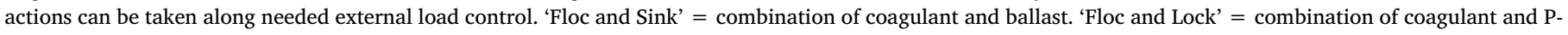
fixative, 'Lock' = P-fixative. 'Kill, Floc and Sink/Lock' = algaecide followed by a combination of coagulant and ballast.

2013b; Copetti et al., 2016), and recently also LMB additions to the 250 ha sized Lagoa da Pampulha (Brazil) have been started. These applications illustrate that geo-engineering interventions will be particularly powerful in smaller sized water bodies. A lot of those smallsized stagnant water bodies are close to urbanized areas and are of great importance to societies (Waajen et al., 2014). Since small water bodies 


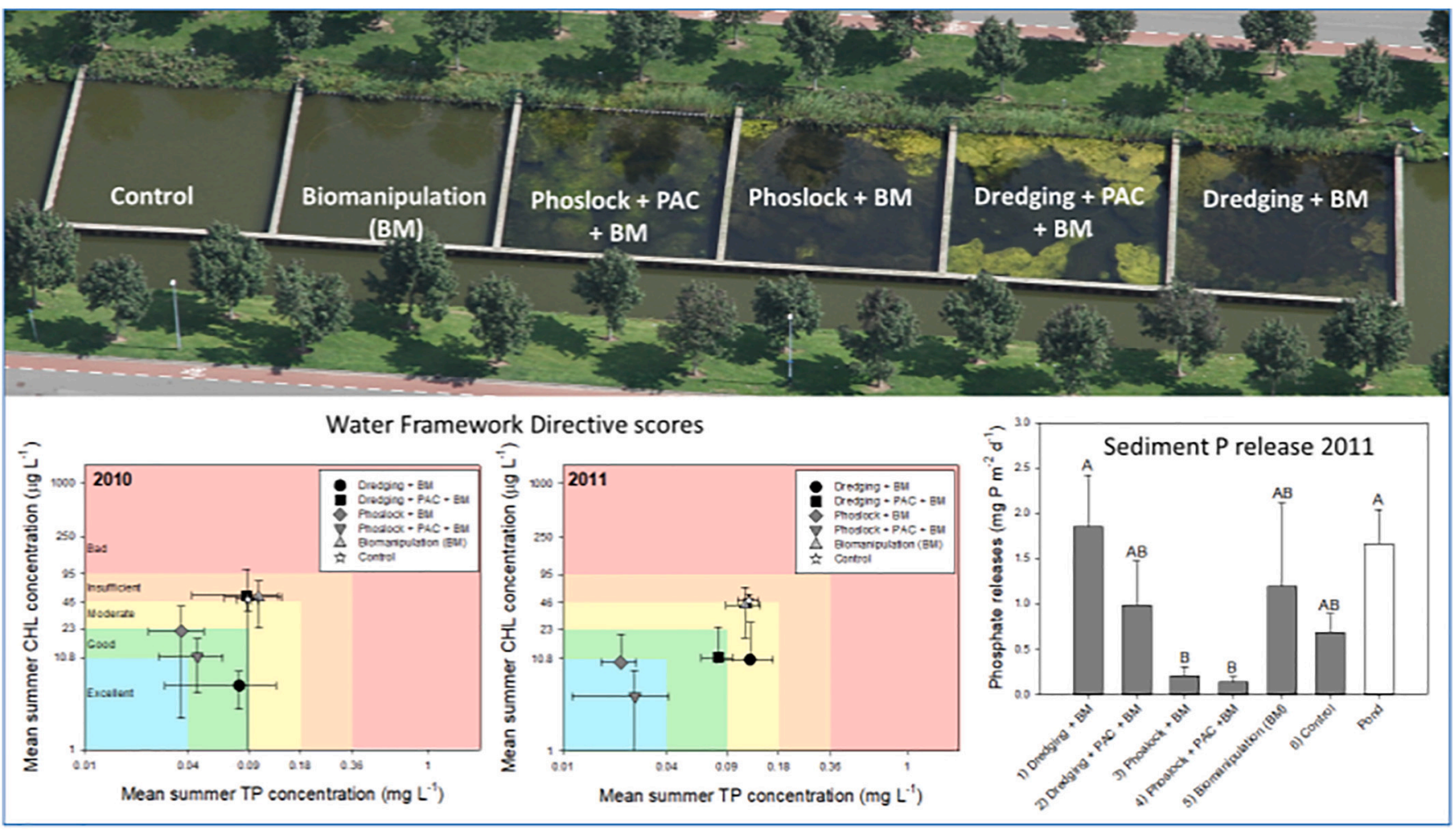

Fig. 6. Example of testing combined measures in a shallow, urban pond (Eindhoven, the Netherlands). Biomanipulation (BM, fish stock reduction and introduction macrophytes) was not sufficient to change the water from turbid to clear, but combined with chemical P fixation in the sediment (using Phoslock ${ }^{\circledR}$ ) or sediment nutrient removal (Dredging), the water became clear with abundant macrophytes and a good water quality was achieved (in the two consecutive years of the experiment; Waajen et al., 2016b). Chemical P inactivation reduced sediment P release, dredging exposed former agricultural soil (Waajen et al., 2016b).

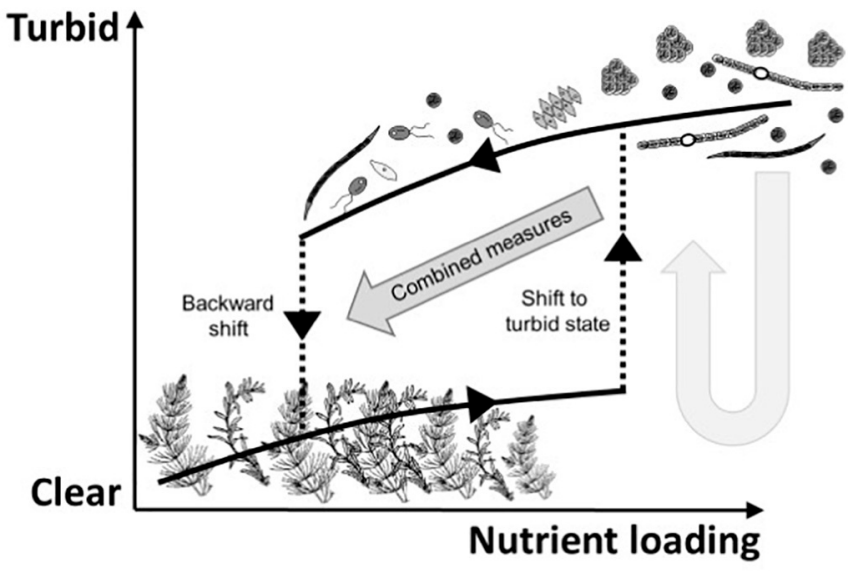

Fig. 7. Hysteresis in a typical shallow lake in which increased nutrient loading leads to a shift from a clear water state with submerged macrophytes to a phytoplankton-dominated state, where the critical point of return is at lower loading than the transition to a turbid state (cf. Scheffer et al., 1993). Shifts indicated by dotted lines. Combined measures reducing turbidity and lowering nutrient load far enough (grey arrow) will bring a system in a clear water state. Above the critical loading, effects will be short-lived and the system will return to a turbid state (light grey arrow). (Redrawn from Lürling et al., 2016b).

are relatively easy diagnosed, they could make good candidates for geoengineering to improve water quality (Waajen et al., 2016b; Fig. 6).

Large lakes with relatively high external nutrient load can only be protected by lowering the external nutrient load because in-lake measures in waterbodies of thousands of $\mathrm{km}^{2}$ will be impractical and too expensive (Paerl et al., 2016). In some cases, however, compartmenting (Stroom and Kardinaal, 2016) and using within-compartment measures
Table 1

Overview of price estimates for different coagulants and potential ballast compounds. Prices derived from www.alibaba.com (assessed March 28th 2020), ${ }^{1}$ pers. comm. Dr. G. Waajen, ${ }^{2}$ indicated by Phoslock Environmental Technologies. ${ }^{1,2}$ are modified compounds aimed to reduce the sediment P-release, but can also be used as ballast in "Floc and Lock" interventions.

\begin{tabular}{|c|c|c|c|}
\hline Coagulant & Price (USD per ton) & Ballast & $\begin{array}{l}\text { (Price USD per } \\
\text { ton) }\end{array}$ \\
\hline Alum & $130-200$ & Sand (sieved) & $100-200$ \\
\hline PAC & $200-400$ & Kaolinite clay & $170-400$ \\
\hline $\mathrm{Fe}(I I I) \mathrm{Cl}_{3}$ & $200-500$ & Bentonite clay & $100-200$ \\
\hline Cationic starch & $200-600$ & Zeolite & $150-300$ \\
\hline Chitosan & $1000-95,000$ & $\mathrm{Al}_{\text {modified }}$ zeolite $^{1}$ & $\sim 2700$ \\
\hline Polyacrylamide & $1200-3000$ & $\begin{array}{l}\text { La modified } \\
\text { bentonite }^{2}\end{array}$ & $2000-2500$ \\
\hline
\end{tabular}

could be a strategy for nuisance control. Compartmenting might provide an engineering solution to drinking water issues for instance in a created compartment, but it will not solve eutrophication issues in the large lake.

Resuming, a lake system analysis is key; it will elucidate the main drivers of the cyanobacterial nuisance and assist in designing tailormade solutions. External load reduction is of paramount importance, but in the majority of cases also in-lake interventions will be needed. Watershed or catchment activities aimed at reducing the nutrient leakage to surface waters may take too long to be implemented, may be less effective than assumed and may take decades to centuries until effects become visible (Jarvie et al., 2013; Rissman and Carpenter, 2015; Goyette et al., 2018). In-lake measures may reduce nuisance and/ or speed-up recovery, the most promising strategy will follow from the diagnosis. "Floc and Sink" strategies using an appropriate coagulant and ballast compounds can remove cyanobacteria effectively from the 
epilimnion and transport them to the sediment. "Floc and Lock" strategies or only P-fixation can be powerful techniques to control internal $\mathrm{P}$ load. In many water bodies, a reapplication will be needed. This can be within one season, or every year in waters with ongoing external load (point source, diffuse or both) or even within several years to decades in waters with a relatively small diffuse load. All in all, geoengineering techniques provide valuable possibilities in the tool-box of lake managers and water authorities to minimize the impact of cyanobacterial nuisance in lakes, ponds and reservoirs.

\section{Declaration of Competing Interest}

None.

\section{Acknowledgements}

Li Kang is sponsored by a CSC Grant (China). VLMH and MMM are partially supported by the National Council for Scientific and Technological Development (CNPq), Brazil. This review is part of the CAPES-ANA project (Coordenação de Aperfeiçoamento de Pessoal de Nível Superior (CAPES)/Agência Nacional de Águas (ANA), Brazil and CIANO-Control project (CNPq, Brazil) and was partly conducted under the flag of the CAPES (Brazil)/NUFFIC (The Netherlands) project 045/ 12.

\section{References}

Bartoszek, L., Koszelnik, P., 2015. Chapter 8, Lakes and reservoirs restoration - Short description of the chosen methods. In: Tomaszek, J., Koszelnik, P. (Eds.), Progress in Environmental Engineering. Water, Wastewater Treatment and Environmental Protection Issues. CRC Press, London, pp. 51-58.

Beaulieu, J.J., DelSontro, T., Downing, J.A., 2019. Eutrophication will increase methane emissions from lakes and impoundments during the 21st century. Nat. Commun. 10 (1), 1-5.

Behets, G.J., Mubiana, K.V., Lamberts, L., Finsterle, K., Traill, N., Blust, R., d'Haese, P.C., 2020. Use of lanthanum for water treatment A matter of concern? Chemosphere 239, 124780.

Bishop, W.M., Richardson, R.J., 2018. Influence of Phoslock ${ }^{\oplus}$ on legacy phosphorus, nutrient ratios, and algal assemblage composition in hypereutrophic water resources. Environ. Sci. Pollut. Res. 25 (5), 4544-4557.

Bishop, W.M., McNabb, T., Cormican, I., Willis, B.E., Hyde, S., 2014. Operational evaluation of Phoslock phosphorus locking technology in Laguna Niguel Lake, California. Water Air Soil Pollut. 225 (7), 2018.

Butusov, M., Jernelöv, A., 2013. Phosphorus: an element that could have been called Lucifer. In: SpringerBriefs in Environmental Science. 9 Springer New York Heidelberg, Dordrecht London. https://doi.org/10.1007/978-1-4614-6803-5_1.

Camacho, F.P., Sousa, V.S., Bergamasco, R., Ribau Teixeira, M., 2017. The use of Moringa oleifera as a natural coagulant in surface water treatment. Chem. Eng. J. 313, 226-237.

Carpenter, S.R., 2005. Eutrophication of aquatic ecosystems: bistability and soil phosphorus. Proc. Natl. Acad. Sci. 102 (29), 10002-10005.

Cline, J.M., East, T.L., Threlkeld, S.T., 1994. Fish interactions with the sediment-water interface. Hydrobiologia 275 (276), 301-311.

Coloma, S.E., Dienstbier, A., Bamford, D.H., Sivonen, K., Roine, E., Hiltunen, T., 2017. Newly isolated Nodularia phage influences cyanobacterial community dynamics. Environ. Microbiol. 19 (1), 273-286.

Cooke, G.D., Welch, E.B., Peterson, S., Nichols, S.A., 2005. Restoration and Management of Lakes and Reservoirs. CRC press, Boca Raton.

Copetti, D., Finsterle, K., Marziali, L., Stefani, F., Tartari, G., Douglas, G., Reitzel, K., Spears, B., Winfield, I., Crosa, G., Haese, P., Lürling, M., 2016. Eutrophication management in surface waters using lanthanum-modified bentonite: a review. Water Res. 97, 162-174.

Cordell, D., Drangert, J.O., White, S., 2009. The story of phosphorus: global food security and food for thought. Glob. Environ. Chang. 19 (2), 292-305.

Cullen, P., Forsberg, C., 1988. Experiences with reducing point sources of phosphorus to lakes. Hydrobiologia 170 (1), 321-336.

Dai, G., Zhong, J., Song, L., Guo, C., Gan, N., Wu, Z., 2015. Harmful algal bloom removal and eutrophic water remediation by commercial nontoxic polyamine-co-polymeric ferric sulfate-modified soils. Environ. Sci. Pollut. Res. 22, 10636-10646.

D’Haese, P.C., Douglas, G., Verhulst, A., Neven, E., Behets, G.J., Vervaet, B.A., Finsterle, K., Lürling, M., Spears, B., 2019. Human health risk associated with the management of phosphorus in freshwaters using lanthanum and aluminium. Chemosphere 220, 286-299.

De Julio, M., Fioravante, D.A., De Julio, T.S., Oroski, F.I., Graham, N.J.D., 2010. A methodology for optimising the removal of cyanobacteria cells from a Brazilian eutrophic water. Braz. J. Chem. Eng. 27 (1), 113-126.

de Lucena-Silva, D., Molozzi, J., dos Santos Severiano, J., Becker, V., de Lucena Barbosa,
J.E., 2019. Removal efficiency of phosphorus, cyanobacteria and cyanotoxins by the "flock \& sink" mitigation technique in semi-arid eutrophic waters. Water Res. 159, 262-273.

de Magalhães, L., Pessoa Noyma, N., Lima Furtado, L., Drummond Oliveira Dias, E., Balthazar Gonçalves Leite, V., Mucci, M., Van Oosterhout, F., Huszar, V.L.M., Lürling, M., Manzi Marinho, M., 2019. Managing eutrophication in a tropical brackish water lagoon: testing lanthanum modified clay and coagulant for internal load reduction and cyanobacteria bloom removal. Estuar. Coasts 42 (2), 390-402.

de Oliveira Ruiz Moreti, L., Takaoka, A.B., Marquettotti Salcedo Vieira, A., Mantovani, D., Bergamasco, R., 2019. The use of Moringa oleifera seeds and their fractionated proteins for Microcystis aeruginosa and microcystin-LR removal from water. Can. J. Chem. Eng. 97 (S1), 1307-1316.

de Vicente, I., Huang, P., Andersen, F.O., Jensen, H.S., 2008. Phosphate adsorption by fresh and aged aluminum hydroxide. Consequences for lake restoration. Environ. Sci. Technol. 42 (17), 6650-6655.

Deng, W., Monks, L., Neuer, S., 2015. Effects of clay minerals on the aggregation and subsequent settling of marine Synechococcus. Limnol. Oceanogr. 60 (3), 805-816.

Dithmer, L., Nielsen, U.G., Lürling, M., Spears, B.M., Yasseri, S., Lundberg, D., Jensen, N.D., Reitzel, K., 2016. Responses in sediment phosphorus concentrations and composition across 10 lakes following applications of lanthanum modified bentonite. Water Res. 97, 101-110.

Douglas, G.B., 2002. US Patent 6350383: Remediation Material and Remediation Process for Sediments.

Douglas, G.B., Robb, M.S., Coad, D.N., Ford, P.W., 2004. A review of solid phase adsorbents for the removal of phosphorus from natural and wastewaters. In: ValsamiJones, E. (Ed.), Phosphorus in Environmental Technology e Removal, Recovery. Applications. IWA Publishing, pp. 291-320 (Chapter 13).

Douglas, G.B., Hamilton, D.P., Robb, M.S., Pan, G., Spears, B.M., Lurling, M., 2016. Guiding principles for the development and application of solid-phase phosphorus adsorbents for freshwater ecosystems. Aquat. Ecol. 50, 385-405.

Downing, J.A., 2014. Limnology and oceanography: two estranged twins reuniting by global change. Inland Waters 4, 215-232.

Du, P., Li, X., Yang, Y., Fan, X., Zhang, T., Wang, N., Li, H., Ji, S., Zhou, Z., 2020. Effect of rapid-mixing conditions on the evolution of micro-flocs to final aggregates during two-stage alum addition. Environ. Technol. https://doi.org/10.1080/09593330. 2020.1723710.

Edmondson, W.T., Anderson, G.C., Peterson, D.R., 1956. Artificial eutrophication of Lake Washington. Limnol. Oceanogr. 1 (1), 47-53.

EEA, European Environment Agency, 2018. Ecological status of surface water bodies. https://www.eea.europa.eu/ themes/water/european-waters/water-quality-and-waterassessment/water-assessments/ecological-status-ofsurface-water-bodies.

Egemose, S., Reitzel, K., Andersen, F.Ø., Flindt, M.R., 2010. Chemical lake restoration products: sediment stability and phosphorus dynamics. Environ. Sci. Technol. 44, 985-991.

Epe, T.S., Finsterle, K., Pall, K., Yasseri, S., 2020. Control of emerging benthic cyanobacteria mats in an Austrian lake. Inland Waters submitted.

EU, European Union, 2013. Seventh Report on the Implementation of the Urban Waste Water Treatment Directive (91/ 271/EEC), COM (2013) 574 final.

Fastner, J., Abella, S., Litt, A., Morabito, G., Vörös, L., Pálffy, K., Straile, D., Kümmerlin, R., Matthews, D., Phillips, M.G., Chorus, I., 2016. Combating cyanobacterial proliferation by avoiding or treating inflows with high P load-experiences from eight case studies. Aquat. Ecol. 50, 367-383.

Friedman, A.A., Peaks, D.A., Nichols, R.L., 1977. Algae separation from oxidation pond effluents. J. Water Pollut. Control Fed. 49 (1), 111-119.

Gebbie, P., 2001. Using polyaluminium coagulants in water treatment. In: Proc. $64^{\text {th }}$ AWIEO Conference, pp. 39-47.

Goyette, J.O., Bennett, E.M., Maranger, R., 2018. Low buffering capacity and slow recovery of anthropogenic phosphorus pollution in watersheds. Nat. Geosci. 11, 921-925.

Gulati, R.D., van Donk, E., 2002. Lakes in the Netherlands, their origin, eutrophication and restoration: state-of-the-art review. Hydrobiologia 478, 73-106.

Hamilton, D.P., Salmaso, N., Paerl, H.W., 2016. Mitigating harmful cyanobacterial blooms: strategies for control of nitrogen and phosphorus loads. Aquat. Ecol. 50, 351-366.

Huang, C., Chen, Y., 1996. Coagulation of colloidal particles in water by chitosan. J. Chem. Technol. Biotechnol. 66 (3), 227-232.

Huang, Y., Xu, L., Han, R., Wang, G., Wang, J., Jia, J., Zhang, P., Pang, Y., 2015. Using chitosan-modified clays to control black-bloom-induced black suspended matter in Taihu Lake: deposition and resuspension of black matter/clay flocs. Harmful Algae 45, 33-39.

Huisman, J., Codd, G.A., Paerl, H.W., Ibelings, B.W., Verspagen, J.M., Visser, P.M., 2018. Cyanobacterial blooms. Nat. Rev. Microbiol. 16 (8), 471-483.

Huser, B.J., Futter, M., Lee, J.T., Perniel, M., 2016a. In-lake measures for phosphorus control: The most feasible and cost-effective solution for long-term management of water quality in urban lakes. Water Res. 97, 142-152.

Huser, B.J., Egemose, S., Harper, H., Hupfer, M., Jensen, H., Pilgrim, K.M., Reitzel, K., Rydin, E., Futter, M., 2016b. Longevity and effectiveness of aluminum addition to reduce sediment phosphorus release and restore lake water quality. Water Res. 97, $122-132$.

Huser, B.J., Bajer, P.G., Chizinski, C.J., Sorensen, P.W., 2016c. Effects of common carp (Cyprinus carpio) on sediment mixing depth and mobile phosphorus mass in the active sediment layer of a shallow lake. Hydrobiologia 763 (1), 23-33.

Ibisch, R., Austnes, K., Borchardt, D., Boteler, B., Leujak, W., Lukat, E., Rouillard, J., Schmedtje, U., Solheim, A.L., Westphal, K., 2016. European assessment of eutrophication abatement measures across land-based sources, inland, coastal and marine waters. In: European Topic Centre on Inland, Coastal and Marine Waters 
(ETC-iCM). UFZ, Magdeburg, Germany.

Iwinski, K.J., Calomeni, A.J., Geer, T.D., Rodgers Jr., J.H., 2016. Cellular and aqueous microcystin-LR following laboratory exposures of Microcystis aeruginosa to copper algaecides. Chemosphere 147, 74-81.

Jančula, D., Maršálek, B., 2011. Critical review of actually available chemical compounds for prevention and management of cyanobacterial blooms. Chemosphere 85 (9), $1415-1422$.

Jarvie, H.P., Sharpley, A.N., Spears, B., Buda, A.R., May, L., Kleinman, P.J.A., 2013. Water quality remediation faces unprecedented challenges from "legacy phosphorus". Environ. Sci. Technol. 47 (16), 8997-8998.

Jeppesen, E., Kronvang, B., Meerhof, M., Søndergaard, M., Hansen, K.M., Andersen, H.E., Lauridsen, T.L., Liboriussen, L., Beklioglu, M., Özen, A., Olesen, J.E., 2009. Climate change effects on runoff, catchment phosphorus loading and lake ecological state, and potential adaptations. J. Environ. Qual. 38 (5), 1930-1941.

Johannesson, K.H., Lyons, W.B., 1994. The rare earth element geochemistry of Mono Lake water and the importance of carbonate complexing. Limnol. Oceanogr. 39, $1141-1154$.

Jones, G.J., Orr, P.T., 1994. Release and degradation of microcystin following algicide treatment of a Microcystis aeruginosa bloom in a recreational lake, as determined by HPLC and protein phosphatase inhibition assay. Water Res. 28 (4), 871-876.

Kong, M., Chen, X.G., Xing, K., Park, H.J., 2010. Antimicrobial properties of chitosan and mode of action: a state of the art review. Int. J. Food Microbiol. 144, 51-63.

Lama, S., Muylaert, K., Karki, T.B., Foubert, I., Henderson, R.K., Vandamme, D., 2016. Flocculation properties of several microalgae and a cyanobacterium species during ferric chloride, chitosan and alkaline flocculation. Bioresour. Technol. 220, 464-470.

Laughinghouse IV, H.D., Lefler, F.W., Berthold, D.E., Bishop, W.M., 2020. Sorption of dissolved microcystin using lanthanum-modified bentonite clay. J. Aquat. Plant Manag. 58, 72-75.

Lee, C.S., Robinson, J., Chong, M.F., 2014. A review on application of flocculants in wastewater treatment. Process Saf. Environ. 92 (6), 489-508.

Li, H., Pan, G., 2015. Simultaneous removal of harmful algal blooms and microcystins using microorganism-and chitosan-modified local soil. Environ. Sci. Technol. 49 (10), 6249-6256.

Li, J., Song, X., Pan, J., Zhong, L., Jiao, S., Ma, Q., 2013. Adsorption and flocculation of bentonite by chitosan with varying degree of deacetylation and molecular weight. Int. J. Biol. Macromol. 62, 4-12.

Liu, X., Byrne, R.H., 1997. Rare earth and yttrium phosphate solubilities in aqueous solution. Geochim. Cosmochim. Acta 61 (8), 1625-1633.

Liu, H., Du, Y., Wang, X., Sun, L., 2004. Chitosan kills bacteria through cell membrane damage. Int. J. Food Microbiol. 95 (2), 147-155.

Lürling, M., Mucci, M., 2020. Mitigating eutrophication nuisance: in-lake measures are becoming inevitable in eutrophic waters in the Netherlands. Hydrobiologia. https:// doi.org/10.1007/s10750-020-04297-9.

Lürling, M., van Oosterhout, F., 2013. Controlling eutrophication by combined bloom precipitation and sediment phosphorus inactivation. Water Res. 47, 6527-6537.

Lürling, M., Mackay, E., Reitzel, K., Spears, B.M., 2016a. Editorial-A critical perspective on geo-engineering for eutrophication management in lakes. Water Res. 97, 1-10.

Lürling, M., Waajen, G., de Senerpont Domis, L.N., 2016b. Evaluation of several end-ofpipe measures proposed to control cyanobacteria. Aquat. Ecol. 50 (3), 499-519.

Lürling, M., Noyma, N., deMagalhães, L., Miranda, M., Mucci, M., van Oosterhout, F., Huszar, V.L., Marinho, M.M., 2017. Critical assessment of chitosan as coagulant to remove cyanobacteria. Harmful Algae 66, 1-12.

Lürling, M., Smolders, A.J.P., Douglas, G.D., 2020. Internal Phosphorus Loading of Lakes: Causes, Case Studies, and Management. Plantation, FL; J. Ross Publishing. Chapter 5. Method Manage. Internal Load. 77-107.

Ma, X., Wang, Y., Feng, S., Wang, S., 2015. Comparison of four flocculants for removing algae in Dianchi Lake. Environ. Earth Sci. 74 (5), 3795-3804.

Matthijs, H.C., Jančula, D., Visser, P.M., Maršálek, B., 2016. Existing and emerging cyanocidal compounds: new perspectives for cyanobacterial bloom mitigation. Aquat. Ecol. 50 (3), 443-460.

Miranda, M., Noyma, N., Pacheco, F.S., de Magalhães, L., Pinto, E., Santos, S., Soares, M.F.A., Huszar, V.L., Lürling, M., Marinho, M.M., 2017. The efficiency of combined coagulant and ballast to remove harmful cyanobacterial blooms in a tropical shallow system. Harmful Algae 65, 27-39.

Morales, J., De La Noüe, J., Picard, G., 1985. Harvesting marine microalgae species by chitosan flocculation. Aquac. Eng. 4 (4), 257-270.

Moss, B., 2010. Ecology of Freshwaters. A View for the Twenty-First Century, 4th edition. John Wiley \& Sons Ltd, Chichester, West Sussex, UK.

Moss, B., Kosten, S., Meerhoff, M., Battarbee, R.W., Jeppesen, E., Mazzeo, N., Havens, K., Lacerot, G., Liu, Z., De Meester, L., Paerl, H., Scheffer, M., 2011. Allied attack: climate change and eutrophication. Inland Waters 1 (2), 101-105.

Mucci, M., Pessoa Noyma, N., de Magalhães, L., Miranda, M., van Oosterhout, F., Alves Guedes, I., Huszar, V.L.M., Manzi Marinho, M., Lürling, M., 2017. Chitosan as coagulant on cyanobacteria in lake restoration management may cause rapid cell lysis. Water Res. 118, 121-130.

Mucci, M., Maliaka, V., Noyma, N.P., Marinho, M.M., Lurling, M., 2018. Assessment of possible solid-phase phosphate sorbents to mitigate eutrophication: influence of $\mathrm{pH}$ and anoxia. Sci. Total Environ. 619-620, 1431-1440.

Mucci, M., Douglas, G., Lürling, M., 2020. Lanthanum modified bentonite behaviour and efficiency in adsorbing phosphate in saline waters. Chemosphere 249, 126131.

Noyma, N.P., de Magalhães, L., Furtado, L.L., Mucci, M., van Oosterhout, F., Huszar, V.L.M., Marinho, M.M., Lürling, M., 2016. Controlling cyanobacterial blooms through effective flocculation and sedimentation with combined use of flocculants and phosphorus adsorbing natural soil and modified clay. Water Res. 97, 26-38.

Noyma, N.P., de Magalhães, L., Miranda, M., Mucci, M., van Oosterhout, F., Huszar, V.L.M., Marinho, M.M., Lima, E.R.A., Lürling, M., 2017. Coagulant plus ballast technique provides a rapid mitigation of cyanobacterial nuisance. PLoS One 12 (6) e0178976.

O'Neil, M., Davis, T.W., Burford, M.A., Gobler, C.J., 2012. The rise of harmful cyanobacteria blooms: the potential roles of eutrophication and climate change. Harmful Algae 14, 313-334.

OECD, 2014. Water governance in the Netherlands: fit for the future? OECD Studies on Water. https://doi.org/10.1787/9789264102637-en.

OECD, 2017. Diffuse Pollution, Degraded Water: Emerging Policy Solutions. OECD Studies on Water. OECD Publishing Parishttps://doi.org/10.1787/ 9789264269064-en.

Oladoja, N.A., Pan, G., 2015. Modification of local soil/sand with Moringa oleifera extracts for effective removal of cyanobacterial blooms. Sustain. Chem. Pharm. 2, 37-43.

Paerl, H.W., Huisman, J., 2008. Blooms like it hot. Science 320 (5872), 57-58.

Paerl, H.W., Paul, V., 2012. Climate change: links to global expansion of harmful cyanobacteria. Water Res. 46, 1349-1363.

Paerl, H.W., Hall, N.S., Calandrino, E.S., 2011. Controlling harmful cyanobacterial blooms in a world experiencing anthropogenic and climatic-induced change. Sci. Total Environ. 409, 1739-1745.

Paerl, H.W., Gardner, W.S., Havens, K.E., Joyner, A.R., McCarthy, M.J., Newell, S.E., Qin, B., Scott, J.T., 2016. Mitigating cyanobacterial harmful algal blooms in aquatic ecosystems impacted by climate change and anthropogenic nutrients. Harmful Algae 54, 213-222.

Pan, G., Zou, H., Chen, H., Yuan, X., 2006. Removal of harmful cyanobacterial blooms in Taihu Lake using local soils III. Factors affecting the removal efficiency and an in situ field experiment using chitosan-modified local soils. Environ. Pollut. 141 (2), 206-212.

Pan, G., Chen, J., Anderson, D.M., 2011a. Modified local sands for the mitigation of harmful algal blooms. Harmful Algae 10, 381-387.

Pan, G., Yang, B., Wang, D., Chen, H., Tian, B.H., Zhang, M.L., Yuan, X.Z., Chen, J.A., 2011b. In-lake algal bloom removal and submerged vegetation restoration using modified local soils. Ecol. Eng. 37 (2), 302-308.

Pan, G., Dai, L., Li, L., He, L., Li, H., Bi, L., Gulati, R.D., 2012. Reducing the recruitment of sedimented algae and nutrient release into the overlying water using modified soil/ sand flocculation-capping in eutrophic lakes. Env. Sci. Technol. 46, 5077-5084.

Pan, G., Miao, X., Bi, L., Zhang, H., Wang, L., Wang, L., Wang, Z., Chen, J., Ali, J., Pan, M., Zhang, J., Yue, B., Lyu, T., 2019. Modified Local Soil (MLS) technology for harmful algal bloom control, sediment remediation, and ecological restoration. Water 11 (6), 1123.

Parma, S., 1980. The history of the eutrophication concept and the eutrophication in the Netherlands. Hydrobiol. Bull. 14, 5-11.

Pei, H.-Y., Ma, C.-X., Hu, W.R., Sun, F., 2014. The behaviors of Microcystis aeruginosa cells and extracellular microcystins during chitosan flocculation and flocs storage processes. Bioresour. Technol. 151, 314-322.

Poléo, A.B.S., 1995. Aluminium polymerization: a echanism of acute toxicity of aqueous aluminium to fish. Aquat. Toxicol. 31, 347-356.

Reitzel, K., Hansen, J., Andersen, F.Ø., Hansen, K.S., Jensen, H.S., 2005. Lake restoration by dosing aluminum relative to mobile phosphorus in the sediment. Environ. Sci. Technol. 39 (11), 4134-4140.

Reitzel, K., Jensen, H.S., Egemose, S., 2013a. pH dependent dissolution of sediment aluminum in six Danish lakes treated with aluminum. Water Res. 47, 1409-1420.

Reitzel, K., Andersen, F.Ø., Egemose, S., Jensen, H.S., 2013b. Phosphate adsorption by lanthanum modified bentonite clay in fresh and brackish water. Water Res. 47 (8), 2787-2796.

Reitzel, K., Balslev, K.A., Jensen, H.S., 2017. The influence of lake water alkalinity and humic substances on particle dispersion and lanthanum desorption from a lanthanum modified bentonite. Water Res. 125, 191-200.

Renault, F., Sancey, B., Badot, P.M., Crini, G., 2009. Chitosan for coagulation/flocculation processes - an eco-friendly approach. Eur. Polym. J. 45 (5), 1337-1348.

Rissman, A.R., Carpenter, S.R., 2015. progress on nonpoint pollution: barriers \& opportunities. Daedalus 144 (3), 35-47.

Roozen, F.C.J.M., Lürling, M., Vlek, H., van der Pouw Kraan, E., Ibelings, B.W., Scheffer, M., 2007. Resuspension of algal cells by benthivorous fish boosts phytoplankton biomass and alters community structure in shallow lakes. Freshw. Biol. 52 (6), 977-987.

Scheffer, M., Hosper, S.H., Meijer, M.L., Moss, B., Jeppesen, E., 1993. Alternative equilibria in shallow lakes. Trends Ecol. Evol. 8 (8), 275-279.

Sengco, M.R., Li, A., Tugend, K., Kulis, D., Anderson, D.M., 2001. Removal of red-and brown-tide cells using clay flocculation. I. Laboratory culture experiments with Gymnodinium breve and Aureococcus anophagefferens. Mar. Ecol. Prog. Ser. 210 (41), $41-53$.

Shi, W., Tan, W., Wang, L., Pan, G., 2016. Removal of Microcystis aeruginosa using cationic starch modified soils. Water Res. 97, 19-25.

Sinha, E., Michalak, A.M., Balaji, V., 2017. Eutrophication will increase during the $21^{\text {st }}$ century as a result of precipitation changes. Science 357 (6349), 405-408.

Smeltzer, E., Kirn, R.A., Fiske, S., 1999. Long-term water quality and biological effects of alum treatment of Lake Morey, Vermont. Lake Reserv. Manag. 15 (3), 173-184.

Smolders, A.J.P., Lamers, L.P.M., Lucassen, E.C.H.E.T., Van Der Velde, G., Roelofs, J.G.M., 2006. Internal eutrophication: How it works and what to do about it-a review. Chem. Ecol. 22 (2), 93-111.

Søndergaard, M., Jensen, J.P., Jeppesen, E., 1999. Internal phosphorus loading in shallow Danish lakes. Hydrobiologia 408 (409), 145-152.

Spears, B.M., Meis, S., Anderson, A., Kellou, M., 2013a. Comparison of phosphorus (P) removal properties of materials proposed for the control of sediment p release in UK lakes. Sci. Total Environ. 442, 103-110.

Spears, B.M., Lürling, M., Yasseri, S., Castro-Castellon, A.T., Gibbs, M., Meis, S., McDonald, C., McIntosh, J., Sleep, D., Van Oosterhout, F., 2013b. Lake responses 
following lanthanum-modified bentonite clay Phoslock ${ }^{\circledast}$ application: an analysis of water column lanthanum data from 16 case study lakes. Water Res. 47, 5930-5942.

Spears, B.M., Maberly, S.C., Pan, G., Mackay, E., Bruere, A., Corker, N., Douglas, G., Egemose, S., Hamilton, D., Hatton-Ellis, T., Huser, B., Li, W., Meis, S., Moss, B., Lürling, M., Phillips, G., Yasseri, S., Reitzel, K., 2014. Geo-Engineering in Lakes: A Crisis of Confidence? Environ. Sci. Technol. 48, 9977-9979.

Spears, B.M., Mackay, E.B., Yasseri, S., Gunn, I.D.M., Waters, K.E., Andrews, C., Cole, S., de Ville, M., Kelly, A., Meis, S., Moore, A.L., Nürnberg, G.K., van Oosterhout, F., Pitt, J.A., Madgwick, G., Woods, H.J., Lürling, M., 2016. Lake responses following lanthanum-modified bentonite (Phoslock ${ }^{\circledast}$ ) application: a meta-analysis of water quality and aquatic macrophyte responses across 18 lakes. Water Res. 97, 111-121.

Steinman, A.D., 2019. Response to Osgood Comment: alum efficiency 11 years following treatment: phosphorus and macroinvertebrates. Lake Reserv. Manag. 35 (1), 4-7.

Stroom, J.M., Kardinaal, W.E.A., 2016. How to combat cyanobacterial blooms: strategy toward preventive lake restoration and reactive control measures. Aquat. Ecol. 50 (3), 541-576.

Van Hullebusch, E., Auvray, F., Deluchat, V., Chazal, P.M., Baudu, M., 2003. Phosphorus fractionation and short-term mobility in the surface sediment of a polymictic shallow lake treated with a low dose of alum (Courtille Lake, France). Water Air Soil Pollut. 146 (1-4), 75-91.

Van Liere, L., Gulati, R.D., 1992. Restoration and recovery of shallow eutrophic lake ecosystems in The Netherlands: epilogue. Hydrobiologia 233, 283-287.

van Loosdrecht, M.C.M., Brdjanovic, D., 2014. Anticipating the next century of wastewater treatment. Science 344 (6191), 1452-1453.

van Oosterhout, F., Waajen, G., Yasseri, S., Marinho, M.M., Noyma, N.P., Mucci, M., Douglas, G., Lürling, M., 2020a. Lanthanum in Water, Sediment, Macrophytes and chironomid larvae following application of Lanthanum modified bentonite to lake Rauwbraken (The Netherlands). Sci. Total Environ. 706, 135188.

van Oosterhout, F., Yasseri, S., Noyma, N., Huszar, V., Marinho, M.M., Muccia, M., Waajen, G., Lürling, M., 2020b. Evaluation of a whole lake eutrophication management technique using combined flocculation and in-situ phosphorus immobilization. Inland Waters in revision.

Vandamme, D., Foubert, I., Muylaert, K., 2013. Flocculation as a low cost method for harvesting microalgae for bulk biomass production. Trends Biotechnol. 31 (4), 233-239.

Verspagen, J.M.H., Visser, P.M., Huisman, J., 2006. Aggregation with clay causes sedimentation of the buoyant cyanobacterium Microcystis. Aquat. Microb. Ecol. 44, 165-174.

Waajen, G.W., Faassen, E.J., Lürling, M., 2014. Eutrophic urban ponds suffer from cyanobacterial blooms: dutch examples. Environ. Sci. Pollut. Res. 21 (16), 9983-9994.

Waajen, G., van Oosterhout, F., Douglas, G., Lürling, M., 2016a. Management of eutrophication in Lake De Kuil (the Netherlands) using combined flocculant-lanthanum modified bentonite treatment. Water Res. 97, 83-95.

Waajen, G., van Oosterhout, F., Douglas, G., Lürling, M., 2016b. Geo-engineering experiments in two urban ponds to control eutrophication. Water Res. 97, 69-82.

Wang, Z., Li, D., Qin, H., Li, Y., 2012. An integrated method for removal of harmful cyanobacterial blooms in eutrophic lakes. Environ. Pollut. 160, 34-41.

Wang, Z., Wang, C., Wang, P., Qian, J., Hou, J., Ao, Y., Wu, B., 2015. The performance of chitosan/montmorillonite nanocomposite during the flocculation and floc storage processes of Microcystis aeruginosa cells. Environ. Sci. Pollut. Res. 22 (14), 11148-11161.

Wang, Y., Ding, S., Wang, D., Sun, Q., Lin, J., Shi, L., Chen, M., Zhang, C., 2017. Static layer: a key to immobilization of phosphorus in sediments amended with lanthanum modified bentonite (Phoslock $\left.{ }^{\varpi}\right)$. Chem. Eng. J. 325, 49-58.

WWAP (United Nations World Water Assessment Programme), 2017. The United Nations World Water Development Report 2017. In: Wastewater: the Untapped Resource. UNESCO, Paris.

Xiao, F., Ma, J., Yi, P., Huang, J.C.H., 2008. Effects of low temperature on coagulation of kaolinite suspensions. Water Res. 42, 2983-2992.

Yang, R., Li, H., Huang, M., Yang, H., Li, A., 2016. A review on chitosan-based flocculants and their applications in water treatment. Water Res. 95, 59-89.

Younes, I., Sellimi, S., Rinaudo, M., Jellouli, K., Nasri, M., 2014. Influence of acetylation degree and molecular weight of homogeneous chitosans on antibacterial and antifungal activities. Int. J. Food Microbiol. 185, 57-63.

Yu, X., Somasundaran, P., 1996. Role of polymer conformation in interparticle-bridging dominated flocculation. J. Colloid Interface Sci. 177 (2), 283-287.

Zhang, H., Shang, Y., Lyu, T., Chen, J., Pan, G., 2018. Switching harmful algal blooms to submerged macrophytes in shallow waters using geo-engineering methods: evidence from a ${ }^{15} \mathrm{~N}$ tracing study. Environ. Sci. Technol. 52 (20), 11778-11785.

Zou, H., Pan, G., Chen, H., Yuan, X., 2006. Removal of cyanobacterial blooms in Taihu Lake using local soils II. Effective removal of Microcystis aeruginosa using local soils and sediments modified by chitosan. Environ. Pollut. 141 (2), 201-205. 